\title{
Primeras misiones integracionistas latinoamericanas (1810-1826)
}

Edmundo A. Heredia

CONICET, Argentina

En base a la historiografía existente, de carácter disperso y fragmentario, se intenta una interpretación global de las misiones enviadas desde varios de los centros revolucionarios, encaminadas no sólo a comprometer la cooperación en la lucha, sino también a establecer lazos más perdurables, generalmente enmarcados en los temas confederativos.

Las gestiones emprendidas por los emisarios muestran rasgos comunes en cuanto a los factores y circunstancias que debieron afrontar, tales como las dificultades de las comunicaciones en largas distancias, las variadas, y a menudo incompatibles, situaciones políticas y militares de cada país. Las discrepancias en cuanto a la vinculación de las nuevas naciones a otros centros mundiales y, sobre todo, las diferentes interpretaciones en cuanto a principios fundamentales como los de libertad, independencia y soberanía.

De esta manera, quedan expuestos los problemas prácticos y teoricos que condicionaron la actuación de los diputados al Congreso de Panamá.

\section{Introducción}

El tema de la integración latinoamericana ha sido estudiado, analizado, utilizado, vapuleado, declamado. Una profusa bibliografía da cuenta de estas características y aún de otras que con frecuencia corresponden a patrióticos empeños, recursos demagógicos, fiebres nacionalistas, afanes apologéticos, rencores vecinales. También hay, claro está, estudios desapasionados y con un buen grado de objetividad.

Difícil resulta a un latinoamericano sustraerse totalmente de este ambiente, en el que vive y convive; la integración latinoamericana ha sido y es intentada como un recurso válido, quizás el mayor, para el fortalecimiento de sus pueblos y de sus naciones. Por eso se hace necesario todo el esfuerzo posible para no quedar envuelto en apasionamientos ni en localismos, que han sido aquí algunos de los obstáculos para transitar el camino de la integración. 
La intención ha sido la de exponer una reseña más o menos estructurada de los proyectos políticos para la integración latinoamericana hasta el Congreso de Panamá, conforme a los modelos y fórmulas de entonces, y presentar la situación existente en el momento de su instalación. Para ello se han reunido y ordenado los datos de los estudios, en su mayoría tan fragmentarios y parciales, que se han producido hasta ahora.

También se ha querido mostrar que quienes trabajaron por la concertación debieron andar los caminos y navegar los mares; que fue sobre todo una tarea de comunicación, de movimiento de ideas y de personas. Que las enormes distancias y el control de las vías de comunicación por intereses ajenos o contrarios a la integración, fueron un desafío difícil de sobrellevar por los comisionados y portavoces del ideal continentalista. $Y$ que en esas andanzas fueron diseñándose itinerarios y marcándose hitos en algunos casos persistentes y hasta decisivos para el futuro de las relaciones interlatinoamericanas. El andar, a su vez, fue moldeando las ideas, modificándolas y renovándolas, en un proceso de adaptación a las circunstancias cambiantes de cada uno de los tantos escenarios en que se perfilaba el nacimiento de las nuevas nacionalidades.

\section{Los precursores}

El rastreo de los presuntos orígenes de la vocación integracionista en América Latina se introduce en la profundidad de los tiempos. Hay autores, como el argentino Drago ${ }^{\prime}$ y el brasileño Aleixo, ${ }^{2}$ que encuentran en Francisco de Vitoria (1486-1546) las ideas de solidaridad entre naciones y en consecuencia su arraigo en las colonias españolas a través de la enseñanza en las Universidades americanas. El primero cree que también Francisco Suárez (15481617) dejó esa simiente aquí. El segundo estima que Vitoria sostu-

\footnotetext{
1 Drago, Mariano José: El Congreso de Panamá, Buenos Aires, 1970. lia, 1970.

2 Aleixo, José Carlos Brandi: A integração latinoamericana. Considerações, Brasi-
} 
vo conceptos concomitantes, tales como la postulación de un derecho internacional moderno, la defensa de la independencia y autonomía de los pueblos y la negación de los derechos de conquista. Es probable que se trate sólo de una interpretación benevolente del ideario vitoriano.

El brasileño Accioli ${ }^{3}$ entiende que en el Tratado de Madrid, de 1750, no sólo se intentan definir en forma completa los límites entre los dominios portugueses y españoles, sino que además se preanuncia el "panamericanismo", pues el acuerdo establecía que las guerras entre España y Portugal no se trasladarían a América. Resulta difícil aceptar esta tesis, si es que se conviene en que tal principio no se refería a la unidad de América, sino a la distinción de los problemas europeos de los americanos, que debían ser tratados separadamente.

Más consistencia parece tener la creencia de que fueron las doctrinas dieciochescas las que sirvieron de inspiración a los integracionistas de las revoluciones de independencia. Así, el inglés Jeremías Bentham (1748-1832) propuso una desvinculación gradual de las colonias americanas con respecto a sus metrópolis, que culminaría con un tribunal arbitral para mantener las vinculaciones entre sí.

La mayoría de los autores inicia la serie de precursores en pensadores nacidos en América. Hay una coincidencia casi unánime en atribuir al venezolano Francisco de Miranda (1750-1816) la primacía de la enunciación formal y persistente del pensamiento integracionista. ${ }^{4}$ Es evidente que su participación en la revolución francesa aquilató sus ideales de libertad, consolidados luego durante su participación en la revolución de independencia norteamericana, donde llegó a admirar la vocación confederativa de sus pueblos.

Por más de un concepto, Miranda ha sido definitivamente consagrado ya como el Gran Precursor. Fue luchando por la indepen-

3 Accioli, Hildebrando: Raizes ou causas históricas do Panamericanismo, Río de Janeiro, 1953.

4 Reixach Vila, Pere: La integración de América en Francisco de Miranda. En "Boletín de la Academia Nacional de la Historia". Caracas, octubre-diciembre de 1988, ha hecho una detallada y documentada reseña del ideario integracionista de Miranda, que utilizamos aquí. 
dencia de los Estados Unidos en Pensacola cuando expresó, quizá por primera vez, que la independencia de las colonias españolas en América debía ser enmarcada por un acuerdo general que armonizara sus intereses y que conformara un sistema de gobierno común. En 1790 propuso al ministro inglés Pitt que apoyara la formación de una confederación independiente en América bajo la autoridad de un Inça. Al año siguiente lanzó una Carta a los Americanos en la que instaba a la formación de una unión americana independiente. Desde entonces su prédica fue permanente, y se incentivó cuando los criollos se pronunciaron por la independencia.

El Precursor pensó también en dos áreas bien diferenciadas en el continente americano independiente. Estados Unidos y Canadá, por una parte, con el nombre de América; El resto conformaría una gran nación con el nombre de Colombia, con excepción de Cuba y otras islas antillanas, que serían reservadas para naciones europeas comprometidas con ello en salvaguardar las independencias hispanoamericanas. La capital de esta extensísima Colombia sería Panamá, a la que consideraba el centro estratégico y natural del gran espacio.

Más tarde, probablemente admitiendo el carácter utópico de sus proyectos anteriores, ideó una estrecha asociación de la Nueva Granada, Venezuela y Ecuador, y un eje de concertación entre Caracas y Buenos Aires. El conato posterior para establecer ese eje y la creación política de la Gran Colombia señalan la notable previsión de Miranda.

En 1797 se reunió en París con el chileno Manuel José de Salas y el peruano José del Pozo Sucre, ambos jesuitas, y los tres dirigieron una nota al gobierno británico solicitando su apoyo para "la independencia y la unidad de la América meridional". En este plan el río Mississippi debía obrar como frontera entre "las dos grandes naciones que ocupan el continente americano". Es destacable para entonces la visión mirandiana sobre los dos sectores definidos en que se dividiría América más tarde, aunque no separados por los límites anunciados.

Ya en 1808 ha mudado su concepción del mapa, pero manteniendo siempre su idea integracionista. Por esos años piensa en la formación de cuatro grandes Estados en la América española: México-Amé-

Anuario de Estudios Americanos 
rica Central, Venezuela-Nueva Granada-Quito, Perú-Chile y Río de la Plata. En ese mismo año, por directa sugerencia suya, Saturnino Rodríguez Peña presentó en la logia masónica a que ambos pertenecían un proyecto para formar Cortes americanas independientes.

Otros de los precursores fueron el ecuatoriano Francisco Eugenio Espejo (1747-1795) y el peruano Pablo de Olavide (1725-1802); este último fundó en Madrid, en 1795, una asociación secreta con Salas y Pozo, los amigos de Miranda, encaminada a concertar acciones en favor de la independencia.

Notable fue la actividad del neogranadino Manuel Torres, quien instalado en Filadelfia desde 1796, se convirtió en el anfitrión y consejero de numerosos revolucionarios que acudían a los Estados Unidos por motivos diversos, a veces como exiliados por rivalidades internas en sus países de origen. Cumplió con ello su propósito de conectarlos entre sí, promoviendo de esa manera una acción revolucionaria conjunta y la formación de grandes bloques independientes y solidarios. ${ }^{5}$

La labor de Torres fue de extraordinaria trascendencia, pues por entonces los Estados Unidos eran uno de los centros principales donde se convocaban agitadores de la acción emancipadora, provenientes de la generalidad de las colonias españolas. Ese centro adquiriría con los años una importancia capital en la acción revolucionaria continental, siempre con el asesoramiento y la ayuda infatigable de Torres, a su vez vinculado con medios gubernamentales estadounidenses.

Fue también la de Torres la acción más prolongada y persistente en favor de la concertación, pues la llevó a cabo sin interrupciones desde su llegada a los Estados Unidos hasta su muerte, en 1822. Hacia 1819 su idea era la de formar tres grandes bloques: el del Centro, con Nueva Granada y Venezuela; el del Norte, formado por Nueva España, Yucatán y Guatemala; y el del Sur, compuesto por las Provincias del Río de la Plata, Chile y el territorio que

5 Sobre la formación de un grupo de revolucionarios dispuestos a acciones concertadas desde los Estados Unidos, véase Heredia, Edmundo A.: Los Estados Unidos de Buenos Aires y Chile en el Caribe, Buenos Aires, 1984. 
comprendía al Virreinato del Perú. A su vez, estos tres Departamentos debían confederarse en un sistema representativo bajo un gobierno central, encargado de organizar la defensa y concertar un común programa económico; éste debía basarse en un plan de Aduanas, un plan de finanzas —que incluía amonedación, pesas y medidas uniformes- y la creación de un Banco Central. ${ }^{6}$

Tuvo la satisfacción de culminar poco antes de morir uno de sus esfuerzos mayores, como fue el reconocimiento de la independencia de las repúblicas hispanoamericanas por los Estados Unidos y, como representante de la Gran Colombia, pasó entonces a ser el primer diplomático de las nuevas repúblicas acreditado oficialmente ante ese país. Consideró a este reconocimiento como más importante que el de las naciones europeas, y como una oportunidad propicia para estrechar las vinculaciones de la Gran Colombia con Perú, Chile y el Río de la Plata, persistente en su idea de que "la unión y acuerdo con los gobiernos que tenemos al Sur es importantísima". 7

Sus vinculaciones se extendieron desde un extremo a otro de América; aunque sus trascendentes servicios a la causa de estas naciones han sido objeto ya de estudios, son sin embargo poco conocidas sus conexiones con el Río de la Plata. Fue significativo que estimulara en Manuel Moreno las ideas continentalistas de la revolución, mientras éste estuvo exiliado en los Estados Unidos. Moreno actuó como secretario de Torres en la misión colombiana que éste desempeñaba, y desde entonces el argentino sería un ardiente admirador de Bolívar, en quien veía a "la persona que más de cerca se parece al venerable Washington". ${ }^{8}$ Luego, Moreno defende-

6 Archivo Histórico Nacional. Bogotá (en adelante AHNC), Colección Ortega Ricaurte, Caja 290, fols. 5 a 18. De Manuel Torres a Germán Roscio. Filadelfia, 12 de abril de 1819.

7 De Manuel Torres a Pedro Gual. Filadelfia, 11 de abril de 1822. En Hernández de Alba, Guillermo: Origen de la Doctrina Panamericana de la Confederación. "Revista de Historia de América", n. ${ }^{\circ} 22$, México, diciembre de 1946, págs. 370-371.

8 De Manuel Moreno a Juan Paz del Castillo. Buenos Aires, 13 de marzo de 1823. En Lecuna, Vicente: Relaciones diplomáticas de Bolivar con Chile y Buenos Aires, Caracas, 1954, tomo II, págs. 107-110; y en "Boletín de la Academia de la Historia", tomo XV, n." 59, Caracas, julio-septiembre de 1932, págs. 238-240. Es probable que se deba a la pluma de Moreno, activo periodista, la nota apologética con motivo de la muerte de Torres, que bajo el título "la muerte de un sabio y patriota" publicó La Abeja Argentina, de Buenos Aires, 
ría con entusiasmo en la Sala de Representantes de Buenos Aires la participación argentina en el Congreso de Panamá, y hasta fue nominado, en principio, para ser el representante en esa reunión. Sin duda, la vocación integracionista de Moreno se afianzó durante sus actividades junto a Torres, aunque ya conocía bien las ideas bolivarianas a través de los contactos con enviados venezolanos durante su misión en Londres.

Es interesante también destacar que la labor de Torres guardó un estrecho paralelismo y sincronismo con la que desplegaba Miranda. El primero en Estados Unidos y el segundo en Gran Bretaña desarrollaron durante los años anteriores a los pronunciamientos una activa labor de difusión y de compromiso internacional para promover la independencia hispanoamericana bajo el signo de la unidad y la concertación. A su vez, había vinculaciones entre ambos centros, y Miranda participó en las tareas conducidas por Torres cuando coincidió con el neogranadino en los Estados Unidos.

\section{Los integracionistas de la revolución}

Tan pronto se iniciaron las revoluciones de independencia - con la de Caracas en abril de 1810 - el fervor integracionista de los ya iniciados se acrecentó, y a la vez comenzaron a aparecer otros sostenedores que presentaron sus variados proyectos; éstos iban desde la alianza ocasional para ayudarse mutuamente en la lucha armada contra España, hasta la unión estrecha sin término ni condicionamientos.

en su edición del 15 de noviembre de 1822, págs. 315-317. Años después, ya cuando se discutía en Buenos Aires el envío de un representante al Congreso de Panamá, Manuel Moreno envió una nota a Bolívar en la que mencionaba sus trabajos con el "benemérito Torres", y reconocía que desde entonces había quedado "instruido del magnánimo pensamiento concebido por V.E.", esto es extender la campaña militar al Perú si no eran suficientes los empeños de San Martín, "y del plan no menos ilustre de llamar después los nuevos Estados a un Congreso que fijase su código político y relaciones nacionales". Esta nota ha sido publicada en el "Boletín de la Academia Nacional de la Historia", tomo XV, n." 59, Caracas, julio-septiembre de 1932, pág. 240. 
También aquí los autores que se han ocupado del tema atribuyen a diversas personas la prioridad en el tiempo de la idea integracionista luego de producido el hecho revolucionario, asignándole su trascendencia peculiar, pues ahora se trataba de concretar en hechos y disposiciones de gobierno lo que antes se había predicado teóricamente o en gestiones para obtener el apoyo de las potencias. En la adjudicación de estos orígenes casi siempre se deja notar la nacionalidad del historiador en la elección del autor de los primeros proyectos, desnudando así un cuestionable afán por fijar glorias nacionales.

En rigor, la idea ya estaba extendida y de hecho había partidarios en varias de las capitales hispanoamericanas; la formación de gobiernos propios dio la ocasión para que se expresaran sin las restricciones que había impuesto el régimen colonial.

Quizá nuevamente corresponda la primera expresión al mismo Francisco de Miranda, si es que se le concede el intervalo de tiempo entre el pronunciamiento de Caracas y el arribo de la noticia a Londres, donde residía, pues en julio de 1810 dirigió una nota al ministro Richard Wellesley anunciando, como una expresión de anhelos, que "los diversos Virreinatos y Provincias del Norte y Sur América se dividirán en diferentes Estados, de acuerdo con sus límites físicos o políticos; pero ellos proyectan un sistema federal, que dejando a los respectivos Estados una independencia de Gobierno, pueda formar una autoridad central y combinada, como los anfictiones de Grecia".

También fue inmediata la voluntad de concertación de la Junta de Caracas, pues tan pronto quedó instalada remitió una circular a los Cabildos de la América española justificando su movimiento por la ilegitimidad del gobierno metropolitano, y excitando a los Ayuntamientos a que se esmeraran "como el órgano más propio para difundir estas ideas por los pueblos a cuyo frente se hallaran, para despertar su energía y para contribuir a la grande obra de la Confederación Americana Española". 9

9 Transcrita por Etchepareborda, Roberto: El impacto del 19 de abril de 1810 en Buenos Aires. "Revista de Historia" I, n. ${ }^{\circ} 4$, Caracas, 1960, pág. 42. 
Es por entonces cuando el chileno Juan Martínez de Rosas escribe su Catecismo Político-cristiano, en el que da las bases para el establecimiento de un gobierno provisorio hasta la formación de una Confederación de Estados.

La Junta revolucionaria chilena le encargó poco después al jurista Juan de Egaña un Proyecto de Declaración de Derechos, en el que éste postuló la unión de los pueblos americanos, para lo cual creía conveniente la reunión de un Congreso General Americano. ${ }^{10}$

En su proyecto, Egaña sostenía que "los Pueblos de América necesitan que, quedando privativa a cada uno su economía interior, se reúnan para la seguridad exterior contra los proyectos de Europa, y para evitar las guerras entre sí, que aniquilarían estas Sociedades nacientes". Adviértase que no hacía distinciones entre las naciones europeas, y que por tanto la liga no debía ser sólo contra España; y que otro peligro que debía aventarse eran las guerras entre las futuras naciones, con lo que su advertencia aparecía como una clara premonición. El segundo artículo de su declaración era también una llamada de alerta, al afirmar que "es muy difícil que cada pueblo por sí solo sostenga, aún a fuerza de peligros, una soberanía aislada".

La preservación de las agresiones europeas no sólo debía ser asegurada mediante la solidaridad, sino también por acuerdos con las mismas naciones europeas; "por este principio --decía Egaña en el artículo tercero- no debe establecerse la clase y naturaleza de sus soberanías, hasta hallarse de acuerdo entre sî'. Esto es, el afianzamiento de la nacionalidad debía ser a partir de la previa concertación entre estos países, y no a la inversa. También mostraba clarividencia en este aspecto, pues el orden propuesto indicaba la primacía de los intereses generales por encima de los intereses lo-

10 Proyecto de una declaración de los derechos del pueblo de Chile, consultado en 1810 por el Supremo Gobierno, y modificado según el dictamen que por orden de él mismo y del alto Congreso, se pidió a su autor en 1811. En Álvarez, Alejandro: La diplomacia de Chile durante la emancipación y la Sociedad Internacional Americana, Madrid, 1910. También ha sido atribuida a José Gregorio Argomedo la autoría de la primera propuesta de un americano para la realización de un Congreso General, en un proyecto presentado el 12 de septiembre de 1810. Mújica, Juan: Relaciones chileno-peruanas durante el gobierno de Bolívar. En "Quinto Congreso Internacional de Historia de América", tomo IV, Lima, 1972. 
cales, en el entendimiento de que los segundos estarían mejor resguardados con esa previa concertación.

La experiencia diría luego que el camino contrario, esto es la afirmación de las soberanías nacionales previas a la concertación, y el condicionamiento absoluto de ésta a las primeras, desbarataría todos los intentos integracionistas, considerados de una u otra manera como lesivos de las soberanías ya establecidas.

Para fijar formalmente estos principios, Egaña terminaba proponiendo que el gobierno dictara una ley por la cual se estableciera que "el pueblo de Chile retiene en sí el derecho y ejercicio de todas sus relaciones exteriores, hasta que, formándose un Congreso General de la nación o la mayor parte de ella, o a lo menos de la América del Sur (si no es posible la nación), se establezca el sistema general de unión y mutua seguridad, en cuyo caso transmite al Congreso todos los derechos que se reservan en este artículo".

Los más notable, como puede apreciarse, es que consideraba una nación única a todas las colonias en lucha por su emancipación de España, y a Chile como una parte natural de esa nación, como una Provincia. Así, el ejercicio de las relaciones exteriores por el gobierno chileno debía ser hasta que un Congreso General americano las asumiera. Otro artículo de la ley proyectada explicitaba aún más la idea, al afirmar que "Chile forma una nación con los pueblos españoles que se reúnan o declaren solemnemente querer reunirse al Congreso General, constituido de un modo igual y libre".

Por último, instaba a que el gobierno de Chile diera parte inmediatamente "a todos los Gobiernos de la nación de las presentes declaraciones, para que, por medio de sus respectivos comisionados, puedan (si se conforman) acordar el lugar, forma, día y demás circunstancias preliminares a la reunión del Congreso General y su libertad y absoluta igualdad de representación, conforme a la población libre de cada una". No se conocen mayores repercusiones de este valioso documento. Eyzaguirre alude a una nota del gobierno chileno del 26 de enero de 1811 en la que se proponía al gobierno de Buenos Aires su participación para llevar a la práctica la propuesta

Anuario de Estudios Americanos 
de Egaña; " la sugestión no habría tenido respuesta. En todo caso, tampoco tuvo eco eficaz en el gobierno chileno.

Según Alejandro Álvarez, el autor de esta propuesta era un firme admirador del modelo norteamericano y de las ideas de la Ilustración europea, y su pensamiento ya prefiguraba la Doctrina que expondría años más tarde el presidente Monroe. Según Eyzaguirre, Egaña se proponía sobre todo formar un frente común contra las apetencias de las naciones europeas.

Lo concreto es que Egaña proyectó este Congreso Americano, que debía reunirse en Panamá o en Guayaquil, para que resolviera una contribución común en hombres, armas y dinero en favor de la revolución continental. El mismo proyectista hizo en 1812 una presentación a su gobierno, en la que planteaba la relación jurídica de Chile con los "pueblos hermanos", y en 1813 fue el redactor de las instrucciones a Francisco Antonio Pinto, enviado a Gran Bretaña, en las que expresó su "ideal americano".

Este primer proyecto de asamblea general para acordar la unión fue el que postuló una vinculación más estrecha, hablar de la existencia de partes de una misma nación. Luego, las circunstancias en el ambiente fragoroso de la guerra emancipadora irían reduciendo progresivamente los grados de integración en el pensamiento de sus sucesivos postuladores.

En años posteriores, Chile sería un centro importante del integracionismo, sobre todo cuando allí fuera a radicarse el venezolano Andrés Bello, identificado con las ideas bolivarianas y encauzado hacia los acuerdos multilaterales por las vías de un derecho internacional de raigambre americana. José Miguel Carrera, que había bebido la doctrina federalista en los Estados Unidos, sería el más firme sostenedor de estos principios en su escenario preferido, esto es en los campos de batalla.

El mismo Egaña persistiría en sus ideas en años siguientes; así, hacia 1822 pensaba en una Dieta Sudamericana que debía reunir a Buenos Aires, Chile y Perú. Y en 1825 renovó una vez

11 Eyzaguirre, Jaime: Proyectos chilenos de unión americana (1810-1829). "Revista Nacional de Cultura". XXIII, n." 147, Caracas, julio-agosto de 1961. 
más su proyecto, agregando ahora el principio de la múltiple nacionalidad para los ciudadanos de las repúblicas hispanoamericanas y la condición de nación más favorecida en los Tratados entre estas naciones, extensiva a Estados Unidos, España, Portugal, Grecia, Brasil y Haití. ${ }^{12}$

Por entonces el ministro de Chile en Washington, Joaquín Campino, trataba de alentar un acuerdo americano, basado en franquicias comerciales, pero, como lo apunta Eyzaguirre, ya se habían debilitado en su país los esfuerzos hacia la concertación.

\section{Las primeras misiones}

Siendo las de Caracas y Buenos Aires las primeras revoluciones de independencia, a ellas les cabría también la oportunidad de ser las primeras en enviar misiones a otros países para promover la adhesión y la ayuda a su causa. En esas misiones, y de distinta manera, también se encuentran expresiones en torno a los deseos y posibilidades de integración.

La Junta de Caracas envió a Bogotá al chileno - otra vez un chileno- José Cortés de Madariaga, para que concluyera un tratado de alianza y promoviera la unión de Venezuela y Nueva Granada. ${ }^{13}$ Cortés de Madariaga había sido uno de los principales promotores de la formación de la Junta caraqueña, y estaba convencido de la necesidad de concertar las acciones revolucionarias. Su misión obtuvo el mayor éxito con la firma del Tratado Lozano-Madariaga, en 1811, y a partir de entonces los dos países actuarían en conjunto en la lucha contra España. El acuerdo fijaba el compromiso mutuo de establecer, cuando las circunstancias lo permitieran, una Confederación General. Fue el primer arreglo formal entre gobiernos en favor de la concertación.

12 Chaves, Julio César: La idea de la Confederación de América. En "Tercer Congreso Hispanoamericano de Historia. Segundo de Cartagena de Indias", tomo I, Cartagena de Indias, 1962.

13 Mendoza, Cristóbal L.: La misión de Madariaga a Santa Fe. "Boletín de la Academia Nacional de la Historia", n. ${ }^{\circ}$ 72, Caracas, octubre-diciembre de 1935. 
A principios de 1810 , los revolucionarios chilenos enviaron a Buenos Aires al argentino Antonio Álvarez de Jonte, de larga residencia en Chile, con el objeto de que se conectara con los partidarios de la misma causa. Producida la revolución de mayo, la Junta de Buenos Aires comisionó al mismo Álvarez de Jonte para que promoviera en Chile la formación de un gobierno propio; cuando llegó de regreso para cumplir su misión, éste ya se había establecido y sus esfuerzos, por tanto, se encaminaron entonces a la firma de un tratado de ayuda mutua. En este caso la idea de confederación no germinó como en el eje Caracas-Bogotá, aunque sí se concretó una estrecha alianza para la guerra, que luego cobraría impulso con la campaña de San Martín.

Las instrucciones que llevaba el comisionado ya presentaban la naturaleza compleja de los problemas en el Plata, pues la "unión de la América" que el nuevo gobierno de Buenos Aires creía de mutuo provecho era para protegerse de las asechanzas del Brasil; la conveniencia de federarse con Chile, que debía postular Álvarez de Jonte, aparecía así motivada fundamentalmente por ese peligro, más aún que el de la por entonces postrada España. Otras de las instrucciones marcaban un tono de moderación y de cautela, escasamente revolucionario, como lo eran la defensa de los derechos de Fernando VII, el respeto a los principios del derecho público establecido (que, como es obvio, no contemplaba facultades de las colonias para emanciparse), el compromiso de moderación y respeto al orden del nuevo gobierno y la presidencia en cuanto a las pretensiones de Carlota Joaquina. ${ }^{14}$ La federación que eventualmente naciera de sus gestiones debía aparecer así menguada y reticente, recelosa y especulativa.

La contrapropuesta chilena, más abierta y con alusión a un Congreso americano, fue rechazada por Mariano Moreno, entonces el miembro más influyente de la Junta de Buenos Aires; según Drago, la negativa se debió a la inconveniencia de asumir compromi-

14 Buenos Aires, 19 de septiembre de 1810. En Molinari, Diego Luis: La primera Unión del Sur. Orígenes de la frontera austral Argentino-chilena. Patagonia. Islas Malvinas y Antártida. Buenos Aires, 1961, págs. 123-124. 
sos que satisfacían intereses específicos de Chile, no compartidos con Buenos Aires.

El proyecto presentado por Álvarez de Jonte incluía "amistad, unión fraternal y estrecha alianza", la promesa de Buenos Aires de reclamar el reconocimiento de la independencia de Chile en sus tratos con Gran Bretaña, la provisión recíproca de hombres, vituallas y otros aprestos bélicos, etc. ${ }^{15}$ No se hablaba de confederación ni de congreso general americano, aunque sí de federación entre Chile y Buenos Aires, esto último por influencia de Castelli -quien seguiría propagando esas ideas en su campaña al Alto Perú-, según lo ha estudiado Chaves. ${ }^{16}$ Así nació la Primera Unión del Sur.

De todos modos, en la primera mitad de 1811 ya estaban enlazadas la revolución de Caracas con la de Bogotá, por una parte, y la de Buenos Aires con la de Chile, por otra. Estaban diseñadas, casi en boceto, las vinculaciones, los compromisos y las prolongaciones de los movimientos revolucionarios sudamericanos.

Sin embargo, faltaba la comunicación directa entre ambos ejes, como lo deseaba Miranda. Esas comunicaciones se dieron, de manera parcial, a través de los emisarios que caraqueños y porteños enviaron a Londres. En efecto, allí se encontraron las misiones de Bolívar y López Méndez (en las que el residente Miranda fue el experimentado asesor y Andrés Bello el eficiente secretario) y de Matías de Irigoyen, solitario representante de las provincias del Río de la Plata. ${ }^{17}$ Las instrucciones de unos y del otro contrastaban diametralmente, pues en los primeros campeaba la decisión y el arrojo, y en el segundo la preocupación y la cautela. Obviamente, las propuestas de concertación partieron de los venezolanos, y no encontraron eco en el comisionado porteño. Retirados Miranda y Bolívar para tomar las armas en América, López Méndez quedó al frente de la misión, y continuó presionando primero sobre Irigoyen y luego sobre su reemplazante Manuel Moreno, en quien encontró un interlocutor más comprensivo.

15 Santiago de Chile, 21 de marzo de 1811. En Ibídem, págs. 125-127.

16 Chaves, La idea de la Confederación...

17 Véase Heredia, Edmundo A.: Primeras relaciones entre Venezuela y Argentina. En "Anuario de Estudios Americanos", Vol. XXXIX, Sevilla, 1982, págs. 217-249. 
El venezolano llegó a compenetrarse de la problemática rioplatense en materia internacional $\mathrm{y}$, seguramente aceptando las advertencias de los enviados de Buenos Aires, terminó por considerar que el peligro de expansión brasileña afectaba a todos los países limítrofes. Así le participó a su gobierno esta preocupación:

Entre tanto la Casa de Braganza no duerme, y a proporción que se aproxima la subyugación de España, se acerca el momento en que va a reclamar derechos sobre la administración de las Américas. Este punto y todos los otros piden una grande atención de parte de los actuales gobiernos americanos, y para decidirlo sería conveniente la concurrencia de todos ellos. ${ }^{18}$

López Méndez instó también a su gobierno a que "por cualquier medio seguro se estableciesen relaciones con Buenos Aires, Chile y quizás el Perú occidental, que para esta fecha suponemos reunidos a los Patriotas del Río de la Plata". En la misma nota, sostuvo que "una liga general de todos estos pueblos, un comprometimiento de no hacer convenios separados sea con el Brasil, sea con la España, sea con la Inglaterra, en materias que afecten el interés general, es uno de los principios, para presentar los derechos de América con dignidad, y para que se echen las bases de un sistema político, uniformemente entendido". El aviso del comisionado venezolano era demasiado comprometido en esas circunstancias, pues una liga alertada contra tantos posibles poderosos enemigos podía provocar la reacción de éstos. El objetivo más prudente era, claro está, tratar de ganar amigos contra España, y no nuevos enemigos.

Así fue como este intento por cerrar el circuito uniendo los dos ejes, que encontró un adherente decidido en López Méndez, se vio frustrado por la condición que Buenos Aires imponía; por lo demás, estos escarceos ẹran más bien oficiosos que oficiales, pues de ambos lados la representación era ante la Grạn Bretaña y no ante el otro país americano. De todos modos, la postura de López Méndez indica la connivencia y acuerdo a que llegó en sus tratos con Moreno.

18 De Luis López Méndez al secretario de Estado de Caracas. Londres, 4 de septiembre de 1811. En Bello, Andrés: Obras Completas. Caracas, 1959, tomo XI, págs. 88-93. 
Pero por su parte Moreno obraba sólo a título personal, pues carecía de facultades para comprometer con los venezolanos concertaciones revolucionarias que fueran más allá de las declamaciones protocolares sobre la identidad de la causa. El hermetismo de Buenos Aires hacia la concertación impidió también que los comisionados de ambas partes destacados en Londres colaboraran oficialmente entre sí para desarrollar sus gestiones en las Cortes europeas.

La escisión se hizo más pronunciada cuando Venezuela dictó su Constitución, claramente independentista, acto que el gobierno de Buenos Aires consideró impertinente, falto de política y contraproducente para la marcha de los movimientos de emancipación. Esta Constitución, cuyo texto fue enviado por Moreno a su gobierno con expresiones de entusiasmo, decía en su artículo noveno:

...nos obligamos y comprometemos a observar inviolablemente todas y cada una de las cosas que en ella se comprehenden, desde que sea ratificada en la forma que en la misma se previene; protextando, sin embargo, alterar y mudar en cualquier momento estas resoluciones conforme a la mayoría de los pueblos de América que quieran reunirse en un Cuerpo Nacional para la defensa y conservación de su libertad e independencia política... ${ }^{19}$

Como puede apreciarse, la Constitución venezolana incidía nuevamente en la idea ya expresada por Egaña, en el sentido de que el interés integracionista estaba por encima de la soberanía nacional o, si se quiere, que la garantía para mantener esa soberanía era ponerla al amparo de un gobierno general americano; por ello, la Constitución misma disponía su propia modificación si la decisión de los pueblos de América reunidos lo hiciesen necesario para arribar a fórmulas de concertación. El principio de la libertad y de la independencia estaba por encima de la soberanía; los intereses generales de los pueblos emancipados eran reconocidos como superiores a los intereses locales de cada uno de ellos.

La modificación de la Constitución por un interés colectivo de la América española emancipada no era considerada como una men-

19 Díaz Sánchez, Ramón: Paisaje Histórico de la cultura venezolana. Buenos Aires, 1965, pág. 77. 
gua de la libertad e independencia, sino como una afirmación de ellas. Este principio es realmente notable, considerado a la luz de los sucesos posteriores, cuando la mayoría de las naciones latinoamericanas optó por el principio contrario, esto es que sólo en la soberanía absoluta residía la garantía de la libertad e independencia. Tampoco debe confundirse con una tendencia a la centralización, pues el principio sostenido era el de la unión para garantizar las independencias nacionales, esto es la afirmación y la protección de las soberanías y de las libertades locales, todo lo cual configuraba un ideario federalista y continentalista a la vez.

De todos modos, y a pesar de las distintas miras de su gobierno, Manuel Moreno mantuvo un buen trato con los venezolanos, simpatizó con su causa y aún con algunos aspectos de sus métodos diplomáticos y de sus medidas audaces de gobierno, y más adelante sería uno de los mayores postuladores en Buenos Aires de la concertación entre los países americanos.

El encuentro londinense había insinuado una incipiente y frustrada red que comprendía Buenos Aires, Chile, Venezuela y Nueva Granada. Si se tiene en cuenta que Buenos Aires había sido la capital del extenso Virreinato y ahora su gobierno se arrogaba la representatividad de todos sus pueblos, y que Venezuela y Nueva Granada participaban de espacios caribeños y parte estratégica de la América Central (Panamá), se comprende que el entendimiento entre los dos grandes bloques abrazaba la mayor parte del territorio colonial español. Una coalición general de estos países hubiera creado un bloque compacto, poderoso y respetable.

La reticencia argentina impidió que se formara ese tejido, para el que en Venezuela y Nueva Granada, y en menor medida en Chile, había un clima propicio por la convicción de una parte significativa de sus dirigentes.

Con los mismos signos aunque con menor intensidad, fueron los contactos entre venezolanos y argentinos enviados a los Estados Unidos. También allí la iniciativa fue venezolana, cuyo comisionado, Telésforo de Orea, interesó a Diego de Saavedra y a Pedro de Aguirre, enviados por el gobierno de Buenos Aires, para "unir y 
convinar medidas de seguridad recíproca con las nuevas Naciones de América". Los argentinos consideraron muy oportuno este acercamiento, y previeron que "quizá será hoy más urgente, si es que la Corte de Portugal tiene alguna pretensión sobre nosotros"; su móvil, como se ve, era también el peligro lusitano. Por otra parte, veían un inconveniente en el reconocimiento que Buenos Aires seguía haciendo de Fernando VII, en tanto Venezuela se había declarado libre e independiente. ${ }^{20}$

En el caso de Venezuela y Nueva Granada la tendencia parecía ser la de consolidar pactos federativos como etapa previa a la formación de la confederación, en tanto que en el de Buenos Aires y Chile prevalecía la idea de la alianza sólo para sostener la guerra de independencia en común.

En los primeros predominaba el concepto de que las concertaciones en cuanto a las campañas militares y a la estrategia revolucionaria debían ser sólo contra el enemigo común, en tanto que en el Plata debían serlo para la lucha contra los enemigos de uno o de otro, lo que se explica por el interés de obtener aliados contra Brasil, que era sólo enemigo suyo. En cambio, el único enemigo de Chile era España, y en esto Buenos Aires no hacía concesión alguna, pues también lo era propio. Esta tendencia sería persistente, y se constituiría en una de las causas de prolongados desentendimientos en los esfuerzos integracionistas posteriores.

Toda esta diferencia del planteo en las relaciones marcaba una metodología en la política exterior igualmente diferente, y que a la postre resultaría antagónica. En tanto los gobiernos venezolano y neogranadino tendían a un entendimiento general a través de un congreso americano, esto es el establecimiento formal de un sistema de relaciones multilaterales, Buenos Aires persistía desde el sistema de pactos federativos en acuerdos de tipo bilateral, entre dos naciones, pactos que podían ser multiplicados con diferentes naciones pero sin romper la bilateralidad, esto es el compromiso individual de uno hacia otro gobierno, lo que garantizaba y preservaba el sostenimiento

20 Archivo General de la Nación (Buenos Aires), (en adelante AGNA), X-1-5-1. Diego de Saavedra y Pedro de Aguirre a la Junta Ejecutiva de las Provincias del Río de la Plata. Filadelfia, 16 de febrero de 1812. 
de la soberanía nacional en cuanto a que la ruptura de tales pactos no lo comprometía ante terceros.

A ello estaba dispuesto en principio, y sólo a eso, con Chile, y ni tan siquiera a eso se llegó en definitiva. En cambio, se acordó el pacto federativo con Paraguay, en la Convención de 1811, cuyo artículo quinto reconocía la independencia del Paraguay, "federación y alianza indisolubles", "auxiliarse y cooperar mutua y eficazmente con todo género de auxilios". ${ }^{21}$ La Convención fue celebrada por el gobierno paraguayo como un éxito rotundo, lanzando una proclama en la que daba a conocer a su pueblo el propósito común de "federación y alianza indisoluble". 22

Pero este pacto resultaría inocuo en todo sentido, pues a la larga no se cumpliría en ninguna de sus partes. La apelación por parte de Buenos Aires a aquel acuerdo se hizo con motivo de la presencia brasileña en la Banda Oriental; el Triunvirato se dirigió al gobierno paraguayo a comienzos de 1812 expresándole que "sólo la unidad de acción es çapaz de hacernos invencibles, y este Gobierno no duda que $V$. E. uniformará sus operaciones y dará a sus exercitos una dirección acordada con los movimientos y empresas de nuestras armas... Entretanto será bueno llamar la atención de los portugueses por esas fronteras a fin de atacarlos divididos... en los ingleses se nos prepara otro enemigo contra quien es preciso precavernos en tiempo y no hay medio mejor de hacerlo que destruyendo antes a los Portugueses". ${ }^{23}$

Sin duda, la diversificación de los frentes y la multiplicación de enemigos presuntos o reales eran los principales obstáculos para obtener concertaciones y solidaridades, y esto cobró en el Río de la Plata su dimensión mayor.

21 Asunción, 12 de octubre de 1811. En Argentina: Colección de Tratados celebrados por la República Argentina con las naciones extranjeras. Buenos Aires, 1863, páginas $1-4$.

22 Asunción, 12 de octubre de 1811. En Báez, Cecilio: Historia diplomática del Paraguay, precedida de un estudio sociológico de los pueblos mediterráneos que concurrieron a la formación de la nación española. Asunción, 1931-1932, tomo I, págs. 183-186.

23 Del Triunvirato (Chiclana, Sarratea, Rivadavia) a la Junta Gubernativa del Paraguay. Buenos Aires, 7 de enero de 1812. En Vargas Peña, Benjamín: Paraguay-Argentina. Correspondencia diplomática, 1810-1840. Buenos Aires, 1945, pág. 100. 


\section{Bolívar, de Londres a Jamaica}

No es del caso reseñar aquí toda la trayectoria bolivariana en función de su vocación integracionista. Sólo nacionalismos o localismos exacerbados pueden poner en duda que el gran protagonista, el gran propulsor, el gran idealista de la integración latinoamericana fue Simón Bolívar. La fuerza de su acción y de su pensamiento han sido tales que han trascendido largamente su tiempo y se proyectan vivos y poderosos hasta el presente.

No es del caso tampoco discurrir de dónde le llegaron las influencias para abrazar con tanta pasión y persistencia su ideario continentalista. El propósito, ahora, es señalar las rutas que transitaron las misiones integracionistas, las circunstancias y coyunturas con que se encontraron en su camino, y la formación de una red de relaciones - bien que fragmentaria y con profundas fisuras - en la América Latina naciente.

En ese sentido, la trayectoria de Bolívar desde Londres a Jamaica, desde 1810 a 1815 , es a la vez una etapa y un itinerario en los que recoge ideas, las sazona en su propio pensamiento y las incorpora para su bagaje intelectual; y en los que también observa realidades y formula premoniciones que marcarán su accionar en la etapa decisiva de la campaña libertaria, a partir de 1817.

En efecto, con su llegada a Londres como emisario de la Junta de Caracas, en 1810, recibirá y capitalizará el ideario integracionista de Francisco de Miranda, perfeccionando su propio pensamiento ya trabajado en la idea de la revolución continental. Sus diálogos con el Precursor, su convivencia con López Méndez y Bello durante la breve etapa inglesa, debieron ser de reflexión y formulación sobre los caminos posibles del movimiento emancipador. Su regreso a Caracas para luchar contra el dominio español, primero bajo las ordenes de Miranda, luego como jefe absoluto, el fracaso en esa instancia de la guerra, el retiro y la desolación, todas ellas fueron experiencias que demostraron con la fuerza dramática de los hechos la necesidad de la solidaridad para alcanzar el triunfo.

La Carta de Jamaica (1815), justamente célebre, es pues resultado de la culminación de una etapa del itinerario bolivariano, iti- 
nerario tanto físico como mental, pues sus permanentes traslados y viajes le brindaron nuevas vivencias y nuevos datos para la renovación y afirmación de su pensamiento revolucionario.

Interesa aquí señalar de ese documento esencial la mutación del concepto de nación, tal como lo habíamos visto desarrollado por Juan de Egaña y por Francisco de Miranda. Bolívar se muestra partidario ferviente de que la América hispana se constituya en unasola nación, "ya que tiene un origen, una lengua, unas costumbres y una religión"; en este sentido, parece recoger y reconocer la validez de las propuestas de ambos antecedentes. Pero, por otra parte, lo considera una utopía, por sus "climas remotos, situaciones diversas, intereses opuestos, caracteres desemejantes".

Es decir, ya está planteada la idea de la unicidad y de la diversidad, que luego sería asumida por diversos pensadores con mayor perspectiva en el tiempo. La disyuntiva es determinar si ambos caracteres de América Latina son compatibilizables, o si en cambio se destruyen fatalmente entre sí. Está planteado también el gran desafío, puesto que a la vista de esta realidad dual, las fórmulas de convivencia entre los pueblos tienen que estar dadas por el equilibrio que pondere justamente esta realidad ambivalente, y proponga sistemas que respeten y concilien ambos extremos. ${ }^{24}$

Quizá por entonces Bolívar no ha dado la suficiente importancia a un problema esencial como es el constituido por las distancias entre los centros poblados, por la enorme extensión territorial del continente y aún de la mayoría de cada uno de los países, por las dificultades por entonces insuperables de los accidentes geográficos que perturbaban las comunicaciones, por los inmensos espacios vacíos posibles aún de colonización y explotación. Esto es, no veía la gravitación decisiva de la dimensión espacial en el establecimiento

24 Collier ha dado una explicación de la problemática del pensamiento de Bolívar en términos de nacionalidad y supranacionalidad. Véase Collier, Simon: Nationality, nationalism and supranationalism in the writings of Simon Bolivar. "The Hispanic American Historical Review", vol. 63, n.0 1. Durham, febrero de 1983. Nosotros optamos por enfocar el tema desde una perspectiva distinta, la de la oposición entre nacionalismo y americanismo, cuya contradicción fue la apreciada por Bolívar a la vista de las corrientes de pensamiento vigentes entonces entre los intelectuales revolucionarios. 
de relaciones entre las naciones latinoamericanas. Si se exceptúa la expresión bastante confusa que alude a "climas remotos", las razones de las dificultades se apoyaban en la variedad de los acontecimientos políticos y de los rasgos culturales o temperamentales como los factores negativos para la integración. Su enfática expresión: "iQué bello sería que el istmo de Panamá fuese para nosotros lo que el de Corinto para los griegos!", desnuda una patente realidad aparentemente no visualizada por Bolívar, como lo es la sideral disimilitud de superficie de la península griega y del territorio de la América hispana.

De todo modos, ya hay una actitud más realista que la de los precursores con respecto a la reunión de los países que luchaban entonces por su emancipación.

La idea principal de la Carta de Jamaica, la de repercusión inmediata, es la de la reunión de un congreso americano, y en esto también es cauteloso y algo escéptico en cuanto a sus posibilidades, aunque constituye su máxima aspiración.

Sólo es posible conjeturar el efecto que las vicisitudes de la política y de la guerra en Europa produjeron en el ánimo y en el pensamiento de Bolívar en este aspecto. Lo cierto es que estaba presente el recuerdo del reciente Congreso de Viena (1814), que había dispuesto el reacomodamiento del mapa dinástico y de poder europeo tras la caída de Napoleón Bonaparte.

Bolívar no podía dejar de considerar esta realidad y de compararla con la americana, pues aquel ajuste había sido entre los vencedores, y aún entre ellos habían pujado por supremacías en base a su protagonismo en la guerra. En tanto, en América aún faltaba vencer y resolver la cuestión de las supremacías, para pensar en un Congreso como el de Viena. Es más, en 1815 la revolución de independencia americana estaba en franco retroceso, poco menos que generalizado en todos los campos.

Pero también había ocurrido ya el regreso de Napoleón, provocando los cien días de conmoción fragorosa; cuando Bolívar escribía su carta (6 de septiembre de 1815), Napoleón había sido ya derrotado definitivamente en Waterloo (18 de junio); aunque aún no se había constituido la Santa Alianza, Bolívar debió ver con honda 
preocupación - no podía ser de otra manera - la restauración generalizada del legitimismo en Europa.

Es decir, era un observador a la distancia de la realización de un Congreso europeo legitimista y amenazante para la causa americana, de una fugaz resurrección napoleónica y de su derrota final y contundente, lo que hacía presagiar un endurecimiento del conservadurismo y de la restauración concertadas del antiguo orden colonial por obra de una "confederación europea".

Desde la atalaya de Kingston, Bolívar veía un panorama político cargado de negros nubarrones para el futuro de la revolución. No obstante, produjo este documento fundamental, lleno de pasión y de ideas estratégicas para acometer la etapa decisiva de su plan libertador. En su tono grandilocuente, en su matiz dramático, en su prudente optimismo, en su actitud expectante, parecen verse los efectos de los avatares vividos desde Londres a Jamaica, con la pasión de los ideales, el fragor de la lucha, los tropiezos en la suerte de las armas, por una parte. Pero también con la imagen de una Europa que salía de una orgía de guerra y se aprestaba a reordenar el mapa de su continente, y muy posiblemente el de la América colonial.

Las circunstancias históricas de ese momento trascendental, y su trayectoria personal hasta esos años, con todas las vicisitudes y la variedad de escenarios, deben ser estimados por tanto, como componentes significativos que se incorporaron indudablemente a su visión de la revolución y de las perspectivas de la integración a partir de un congreso general.

\section{El emisario mexicano Simón Tadeo Ortiz y Ayala}

La primera misión enviada por un gobierno revolucionario para recorrer los paíșes hispanoamericanos con la propuesta de mancomunar la lucha, partió de México. Es sorprendente el origen de esta misión, pues la intención de los mexicanos de conectarse en un acuerdo multilateral no tenía apoyo de un antecedente previo de relaciones o aproximaciones, y también por la enorme distancia y la dificultad de las comunicaciones con los otros dos centros más importantes de la acción revolucionaria, Caracas y Buenos Aires. 
Hasta entonces, se habían producido entendimientos entre sectores, principalmente los de Buenos Aires con Chile y los de Venezuela con Nueva Granada, y habían resultado tímidos y precarios los intentos de ligar a su vez las dos grandes regiones revolucionarias. Si estas últimas relaciones no habían prosperado, aún frente a la evidencia de intereses comunes sobre un gran espacio contiguo, como era el área cordillerana y platense, menos promisoria era la comisión que el efímero gobierno mexicano de Ignacio Rayón encomendó a Simón Tadeo Ortiz y Ayala, en 1813.

Conviene señalar algunos de los rasgos conocidos de la personalidad y de las andanzas de Ortiz y Ayala para apreciar mejor los orígenes y las características de su acción integracionista, respondiendo así al propósito de poner de relieve la relación existente entre los desplazamientos e itinerarios - $\mathrm{y}$ en ellos las ciudades y naciones recorridas-, con las ideas, los planes y las acciones dirigidos a concertar el movimiento revolucionario de las colonias españolas en proceso de emancipación.

Siendo un joven de 21 años, Ortiz había sido asistente del diputado por Veracruz en las Cortes de Cádiz, Joaquín Maniau, que fue defensor de la apertura de la América española al comercio mundial; en esa oportunidad, Ortiz se relacionó con otro diputado americano, José Álvarez de Toledo, que representaba a Santo Domingo, enrolados ambos en la logia de los Caballeros Racionales; Álvarez de Toledo sería luego un movilizador de la apertura comercial y de la libertad de navegación en aguas antillanas, vinculándose en ciudades portuarias norteamericanas a los corsarios que se movían en esos mares causando estragos a las flotas mercantes españolas.

Toledo y Ortiz coincidirían también en Washington, en 1812, donde trabajaron juntos para ganar la voluntad de dirigentes estadounidenses en favor de la causa revolucionaria. ${ }^{25}$ Allí se vinculó con Bernardo Gutiérrez de Lara, que actuaba en nombre del gobierno mexicano rebelde, y con él se dirigió a Nueva Orleans,

25 En este punto hemos seguido en general el estudio de Timmons, Wilbert H.: Tadeo Ortiz, mexican emissary' extraordinary. "The Hispanic American History Review", LI, n. ${ }^{\circ}$ 3, Durham, agosto de 1971, basado en documentación del Archivo General de Indias de Sevilla, y del Archivo General de la Nación, de Buenos Aires. 
uno de los centros más importantes de la actividad corsaria. Desde allí, Ortiz ofreció sus servicios a los jefes patriotas mexicanos Rayón y Morelos.

Fue así como a fines de 1813 salió desde Nueva Orleans con una diputación confiada por Rayón, con destino a Nueva Granada. Las instrucciones que le fueron entregadas extendían su misión a los gobiernos de la América del Sur, en general, y fijaban como aspiración máxima la unión recíproca de México con los países de esa parte del continente; proponían una alianza ofensiva y defensiva, y un tratado de comercio. En varios artículos de estas instrucciones se insistía en el tema comercial; en uno de ellos se establecía que debía ser ofrecida una total libertad de comercio, para lo cual se destacarían comisiones conjuntas de los países hispanoamericanos a las Cortes extranjeras. A los efectos de una acción eficaz en la lucha contra España, propondría formar una compañía de accionistas de Inglaterra o de Estados Unidos a la que se ofrecería la exclusividad en algunos artículos de comercio y en armas, comprometiéndose a su vez esta compañía a contribuir con aprestos navales. ${ }^{26}$

Ortiz hizo estancias previas en la Cuba española y en la Jamaica inglesa, y arribó a Cartagena en noviembre de 1814; no encontró en las autoridades de esta ciudad ambiente favorable para el cumplimiento de su misión, pero pasó a Bogotá, donde se encontraba en marzo de 1815. Allí presentó poderes que él mismo confeccionó como conferidos por Morelos, y por tanto falsos, con los cuales gestionó un tratado de alianza con la Nueva Granada; ante la indiferencia del gobierno, insistió repetidamente, sin éxito alguno.

Convencido de la inutilidad de sus empeños, pidió sus pasaportes y se retiró del país, regresando a Nueva Orleans, donde renovó sus contactos con revolucionarios y aventureros, algunos de los cuales reunían ambas condiciones. En los años siguientes, viajó por Caracas, Cundimarca, Lima, Quito, Guayaquil y Santiago; su actividad conocida es la de un estudioso de los recursos agrícolas y

26 El texto y comentarios de las instrucciones en Torre Villar, Ernesto de la: Labor diplomática de Tadeo Ortiz, Tlatelolco (México DF), 1974, págs. 111-114. Este estudio incluye apéndices documentales tomados de colecciones mexicanas y de la Colección Latinoamericana de la Biblioteca de la Universidad de Texas. 
minerales de estos países. Por fin, a mediados de 1818 llegó a Buenos Aires, donde entonces ejercía su autoridad el director Pueyrredón. De inmediato ofreció a las autoridades porteñas un pacto de confederación y solicitó una ayuda en armas. Para despertar el interés por este acuerdo, ofreció una tercera parte de los caudales en metálico que recaudara México y propuso la firma de un convenio de comercio. Renovando aquellas instrucciones ya antiguas y obsoletas de Rayón, propuso la formación de una compañía de accionistas. ${ }^{27}$ Presentó también una nota del presidente mexicano fechada más de cinco años antes, conteniendo un saludo al gobierno y facultando a Ortiz "para tratar todo lo que coadyuve a cimentar la independencia de los pueblos americanos". ${ }^{28}$

Se repitió aquí la misma situación de años atrás en Bogotá, pues el secretario Gregorio Tagle no dio respuesta a las instancias de Ortiz, lo que provocó su desaliento. En una de sus notas reclamando respuesta expuso que las circunstancias le impedían presentarse con carácter público, con lo que reconocía su falta de representatividad oficial. ${ }^{29}$

Torre Villar supone que debió ser visto en Buenos Aires como "un visionario desamparado", razón por la cual las autoridades terminaron recomendándole que fuera a Inglaterra a pedir auxilio, con

27 En este punto se han aprovechado las documentadas referencias de Belgrano, Mario: Don Simón Tadeo Ortiz y Ayala. Comisionado de Méjico en Buenos Aires (1818-1819). "Humanidades", tomo XXV, 1.a parte, La Plata, 1936, obtenidas del Archivo General de la Nación, en Buenos Aires. Como es frecuente en la historiografía argentina, el estudio de Belgrano se refiere solamente a la misión cumplida por Ortiz en Buenos Aires, sin hacer alusión a las actividades que venía cumpliendo desde años atrás en otros países, obviamente vinculadas. Este autor declara no haber encontrado documentación sobre la posible respuesta del gobierno argentino, ni tampoco indicios de que Ortiz fuese recibido por Pueyrredón. Además, Ortiz presentó una copia de sus credenciales extendidas por Ignacio Rayón, bajo el título Credenciales del Presidente del Gobierno libre de México Dn. Ignacio Rayón dirigidas á su Diputado Comisionado, fechadas en el Palacio Nacional de América, Zitaquaro, 16 de enero de 1813, posiblemente confeccionadas para el caso, pues aparece facultado expresamente para tratar con el gobierno de Buenos Aires. Hemos consultado este documento en AGNA, X-1-9-14.

28 AGNA, X-1-9-14. De Ignacio Rayón, presidente, e Ignacio Oyarzábal, secretario de Estado y Gobierno de México, a los Gobiernos de Sud-América (Copia). Palacio Nacional de América. Zitáquaro, 16 de enero de 1813.

29 Ibídem. De Ortiz al director de las Provincias Unidas. Buenos Aires, 4 de septiembre de 1818. 
lo que, según parece evidente, procuraron sacárselo de encima. En efecto, luego de escribir al gobierno de Chile con igual resultado negativo, emprendió viaje a Inglaterra y de ahí pasó a Holanda, Francia y España.

Si bien la gestión desarrollada por Ortiz estaba desprovista de los recaudos diplomáticos mínimos, no por ello sus ideas eran descabelladas en cuanto a la conveniencia de una especie de "confederación económica"; en efecto, la unión que propugnaba era de índole fundamentalmente económica, para lo cual creía conveniente que fueran pocos y fuertes los gobiernos constituidos en la América emancipada de España.

La idea general era complementar las economías, y que se abastecieran estos países recíprocamente, pensando que debía formarse un cuerpo sólido que se opusiera a las penetraciones británica y estadounidense. También creía, como tantos en su época,. que era necesario un vasto plan de colonización que introdujera "razas fuertes" para neutralizar "la indolencia de los autóctonos". 30

Ortiz había observado con sagacidad las riquezas naturales de varios países, además de las de México, y comprendió que la vastedad y diversidad de recursos eran una base aprovechable para desarrollar economías consistentes y un intercambio para todos beneficioso.

En tanto Timmons ha concluido que su aporte a la independencia de México no tuvo importancia, y que utilizó métodos ingenuos, Torre Villar sostiene como algo positivo que el suyo fue probablemente el primer estudio global de la economía latinoamericana. Este solo hecho es suficiente para acreditarlo como un válido precursor de la integración de estos países, aunque en rigor no encontrara por entonces eco en ninguno de ellos.

Otro valor debe rescatarse del periplo de Ortiz, y es que fue la suya la primera misión de tipo continental, que abrazó desde el país más septentrional de la futura América Latina hasta el más meridional. Una causa de su fracaso debió ser, en verdad, la falta de

30 Estas ideas están expuestas en la memoria transcrita por Torre Villar, Labor diplomática..., págs. 122-146, presentada en Buenos Aires, 1819. 
representatividad e incluso sus escasas dotes diplomáticas; pero también le perjudicó el hecho de que cuando llegó a Bogotá, en 1814, las urgencias se concentraban en las circunstancias inmediatas de la guerra, por entonces muy desfavorables y acuciantes; y que cuando llegó a Buenos Aires, en 1818, el gobierno no estaba en condiciones de proveer ayuda por la necesidad de concentrar todos sus recursos en la campaña de Chile y en los conflictos rioplatenses.

Sin embargo, la causa principal de este fracaso debe considerarse dentro del contexto de los diferentes criterios adoptados en la lucha revolucionaria contra España, de las rivalidades internas que ya se desataban en estos países, de los recelos que comenzaban a aflorar entre ellos por cuestiones territoriales, económicas y políticas, y de las posiciones que las potencias tomaban para la explotación de recursos y mercados. Frente a estos poderosos factores, la incompetencia o fragilidad de la misión fue más bien el pretexto que los atareados gobiernos revolucionarios utilizaron para dar la espalda a sus demandas.

\section{El integracionismo con Brasil}

Obviamente, Brasil sólo pudo incorporarse en una etapa posterior a los planes de asociación, por cuanto su independencia data de 1821. Además tenía un modelo diferente al de los países hispanoamericanos; la idea confederativa en las repúblicas tenía como uno de sus principios que el sistema de gobierno que adoptaran los países era esencial y excluyente en los programas de unión. Por tanto, la forma monárquica adoptada por el Brasil independiente era reluctante, en ese aspecto, a una confederación con las repúblicas.

No obstante, desde una y otra parte los dirigentes sentían la necesidad de un acuerdo, pues estaban identificados en el común anhelo de salir de un estado de postración colonial y aspirar a un futuro de independencia y soberanía. Además, la contigüidad geográfica aconsejaba el entendimiento, y la condición de país limítrofe con la mayoría de las repúblicas sudamericanas creaba una relación inexcusable, que debía ocupar la atención preferente de sus hombres de Estado. 
La complejidad creada por antinomias y convergencias era alimentada aún por una vocación imperial que le venía como herencia de la metrópoli portuguesa, y que el mentor de la independencia José Bonifacio sintetizó en la famosa expresión de "Brasil del Amazonas al Plata", ambición tan amplia como vaga, pues dejaba abierta la presunción de que no hablaba de ríos como líneas de frontera, sino de cuencas fluviales como áreas de ocupación. El pomposo nombre de Imperio daba idea de un destino de grandeza, de superioridad, de expansión y hegemonía que no podía menos que hacerles recordar a los demócratas y republicanos vecinos el anterior orden colonial contra el cual aún estaban combatiendo.

Por tanto, fue muy difícil el diálogo entre los vecinos; el gobierno brasileño no logró obtener credibilidad cuando proclamó su decisión de integrarse al sistema americano y de alentar proyectos confederativos. Y decisivamente imposible fue el entendimiento de cualquier proyecto asociativo con el gobierno argentino, que veía amenazados por Brasil sus territorios del sistema platense; el conflicto tuvo una instancia importante, aunque no final, en la guerra cisplatina, desatada en 1825 .

Así cuando el sueño de Bolívar se cumplía en Panamá, Brasil y Argentina estaban envueltos en una cruenta guerra de la cual saldría el Estado uruguayo, una criatura nacida de la discordia, no del afecto. De esa manera, los hechos mostraban con un crudo realismo las profundas contradicciones en que estaban envueltos estos países.

Era lógico que el gobierno brasileño utilizara el argumento del común interés de independizarse de Europa en sus aproximaciones hacia las repúblicas, y que ocultara, disimulara o presentara bajo otros aspectos su vocación expansionista. A poco de pronunciado el grito de Ipiranga, José Bonifacio dirigió una nota a Rivadavia postulando la creación de un sistema americano con el fin de oponerse conjuntamente a las pretensiones reivindicatorias europeas. ${ }^{31} \mathrm{La}$ misma idea la expuso a Correa da Cámara, emisario del gobierno;

31 Soares, Álvaro Teixeira: Das origens do Pan Americanismo á União Panamericana. Río de Janeiro, 1940. 
y el representante en los Estados Unidos, Silvestre Rebello, recibió instrucciones en las que se aludía concretamente al "sistema político de América"y se le encomendaba iniciar tratativas para una Liga ofensiva y defensiva con los Estados Unidos. ${ }^{32}$

En tanto, el ministro Silvestre Pinheiro Ferreira, desde Lisboa, combatía ante las Cortes europeas los propósitos reconquistadores de la Santa Alianza y exponía la conveniencia de formar una confederación hispano-lusitana con el apoyo de los Estados Unidos; su plan incluía una Confederación formada por España, Portugal, los Estados americanos y Grecia, que sería sancionada por un Congreso que debía realizarse en Washington y ser presidido por los Estados Unidos. ${ }^{33}$ Con ese fin envió en 1822 un emisario a Colombia y Buenos Aires, Verissimo Antonio Ferreira da Costa, sin resultados concretos.

Los representantes brasileños en Europa y en Estados Unidos pudieron desarrollar mejor sus habilidades diplomáticas que los que habían enviado años atrás las repúblicas, en ocasión de proclamar su revolución emancipadora. Las circunstancias habían cambiado, pues ya no se trataba de optar o depender de los bandos entonces enfrentados por la ocupación napoleónica. Esto les permitió ver con más claridad la escena y postular con más coherencia sus posiciones. Comprendieron que ya no se trataba de la lucha contra su metrópoli, incapaz de reaccionar por sí sola, sino contra las potencias europeas adictas al absolutismo o empeñadas en su expansión industrial. Se trataba de la amenaza de los países asociados en la Santa Alianza, por una parte, y los demás países industrializados y marineros de Europa, éstos con Inglaterra a la cabeza, que intentarían avanzar sobre las posiciones de las que las metrópolis seculares habían sido desalojadas.

Así, el representante en París, Manoel Rodrigues Gameiro, advirtió a su gobierno en Rio de Janeiro que el reconocimiento de la independencia de los países americanos - tanto las repúblicas como

32 Heredia, Edmundo A.: La diplomacia brasileña ante la cuestión de la Banda Oriental. "Revista-Libro Historia", Año II, n. 6, Buenos Aires, 1982.

33 Accioli, Raizes... 
el mismo Brasil- estaba siendo objeto de especulación entre las potencias, como un negocio del cual cada una quería obtener su rédito a costa de los países emancipados. "Para cubrirse de tal humillación, deben los Estados de la América Meridional hacer ya una Liga entre sí...", era la conclusión de Gameiro. Entre las medidas concretas de esa Liga debían estar la de garantizarse recíprocamente su independencia, hacer una guerra común contra sus metrópolis, cerrar sus puertos a las naciones extranjeras que no reconocieran las independencias, enviar comisiones conjuntas a las naciones europeas para demandar ese reconocimiento y arreglar sus conflictos internos por vía de la mediación. ${ }^{34}$

Hasta aquí la propuesta podía parecer inobjetable a los gobiernos de las repúblicas. Pero en el mismo oficio de Gameiro estaba la contraparte, pues sostenía que los varios hombres de Estado a quienes había expuesto su proyecto entendían "que es su Majestad Imperial a quien compete la gloria de su iniciativa, dirigiendo la negociación con el mayor secreto posible...", con lo que estaba anticipando una condición que las repúblicas no aceptarían. En otra nota a su ministro, Gameiro insistió en la formación de la Liga "porque ella tiende no solamente a acelerar el pretendido reconocimiento, sino también a establecer la supremacía que el Brasil debe lograr entre los demás Estados de la América Meridional". ${ }^{35}$

Eran dos fines diferentes convencionalmente aunados, el uno para asegurar el reconocimiento de la independencia por las naciones europeas, el segundo para obtener de las repúblicas hispanoamericanas el reconocimiento de la superioridad brasileña.

El representante brasileño en Gran Bretaña, Hipólito da Costa, participaba del mismo plan, tratando de obtener el consentimiento de la Gran Colombia a través del enviado de ese gobierno acreditado en Londres, José Manuel Ravenga. Fácil era obtener de su interlocutor consentimiento sobre la formación de la Liga, ya que era

34 De Manoel Rodrigues Gameiro a José Bonifacio de Andrada e Silva. París, 31 de enero de 1823, en Archivo Diplomático da Independencia, Río de Janeiro, Ministerio das Relaçōes Esteriores, 1922-1923, vol. III, págs. 82-83.

35 De Gameiro a José Bonifacio. París, 2 de febrero de 1823. En Archivo Diplomático..., vol III, págs. 83-84. 
éste un anhelo primordial de la Confederación Grancolombiana; pero en cambio no obtendría apoyo para la primacía brasileña, pues se enfrentaba a la ambición de Bolívar de ser el protagonista principal de la unión. Da Costa argumentó que "esta Liga de mutua garantía hará que las potencias marítimas de la Europa se acomoden en breve con el sistema americano, quiéranlo o no; y si la reunión de los Enviados de esas potencias se hiciere en Rio de Janeiro, sin duda será ese el principio de la supremacía que el Imperio del Brasil deberá para el futuro ejercitar en toda la América Meridional, sin que esos Estados se aperciban de las consecuencias, bien como los Estados Unidos la tendrán en la América Septentrional". ${ }^{36}$

Más cauta sería la gestión de Rebello, el representante brasileño en los Estados Unidos, en sus acercamientos al enviado de la Gran Colombia, José María Salazar; quizá el escenario mismo donde se realizaban las entrevistas aconsejaba moderación y prudencia en cuanto a pretensiones de liderazgo. Rebello se mostró allí dispuesto favorablemente a que el Brasil formase parte de una gran Confederación Americana, y a que Colombia actuase de mediadora en las desavenencias entre su gobierno y el argentino. ${ }^{37}$ Las instrucciones que recibió de su ministro privilegiaban el reconocimiento de la independencia por los Estados Unidos, lo que obtuvo sin obstáculo y con rapidez; se le señaló también que debía conectarse preferentemente con los representantes de los otros Estados americanos, "mostrando siempre predilección para con ellos, y afectando una exclusiva parcialidad por la Política Americana". También se le encomendó sondear la disposición del gobierno norteamericano en cuanto a una liga ofensiva y defensiva. ${ }^{38}$

Es probable que no se considerara conveniente enarbolar pretendidas supremacías en los Estados Unidos y sí, en cambio, hacer-

36 De Hipólito José Da Costa a José Bonifacio. Londres, 8 de julio de 1823. En Archivo Diplomático..., vol I, págs. 281-282.

37 AHNC, República Miscelánea, tomo 24, fol. 304. De José María Salazar al secretario de Relaciones Exteriores de Colombia. Filadelfia, 10 de julio de 1824.

38 Instrucções para servirem de regulamento ao snr. José Silvestre Rebello na Commissão em que parte desta Corte para a América Septentrional. Rio de Janeiro, 31 de enero de 1824. Firmadas por Luiz José de Carvalho e Mello. Archivo Diplomático..., vol V, páginas $10-18$. 
lo en Europa. En efecto, nada que apareciera como rasgos imperiales podía favorecer las relaciones con los primeros, en tanto las naciones europeas debían ver con buen ojo que en América se levantara por encima de las repúblicas una monarquía con una legítima dinastía real, con la que las coronas europeas podrían mantener un diálogo amistoso y recíprocamente provechoso, y quizá hasta paternal, en tanto se mantuviese en América el concepto de que las naciones americanas podían seguir siendo filiales de las europeas.

La ambición de liderazgo del Brasil en una eventual confederación o liga aparece expuesta repetidamente por sus ministros y sus diplomáticos, y aún sostenida públicamente en tratativas con las repúblicas hispanoamericanas y ante las naciones europeas. Esta pretensión no podía ser aceptada por las primeras, como es lógico, pues se vio en ella la forma explícita que adquiría la vocación brasileña de constituirse en la cabeza de estos países con la consiguiente amenaza de hegemonía y expansión.

\section{Las misiones preparatorias del Congreso de Panamá}

Cuando en 1820 fue constituida la Confederación Grancolombiana, Bolívar consideró que había consolidado el eje desde el cual podía proponer la convocatoria al Congreso General. Para ello decidió enviar hacia el norte y hacia el sur sendas comisiones que debían comprometer formalmente a los gobiemos a colaborar y participar activamente en la empresa.

Así fue como salieron Miguel de Santamaría, con rumbo a México, y Joaquín Mosquera y Arboleda, con destino al Perú, Chile y Buenos Aires. Era hasta entonces la más seria y más concreta gestión proyectada para cumplir la aspiración largamente esperada. El método era obtener tratados bilaterales, pero al mismo tiempo comprometer la gestión para la adhesión de los otros gobiernos, de modo que esos tratados se convirtieran en un conjunto de acuerdos que por multiplicación se constituirían en una red de convenios multilaterales.

Paradójicamente, en el mismo año en que los dos comisionados eran designados, el representante de Colombia ante las Cortes 
europeas, Francisco Antonio Zea -que por añadidura detentaba entonces la Vicepresidencia de la Gran Colombia - irrumpía desde Londres ante el gobierno de España con un insólito proyecto de confederación Hispanoamericana, presentado al embajador español en Londres, duque de Frías. El plan consistía en el reconocimiento de la independencia, pero acompañado de un compromiso entre las repúblicas hispanoamericanas y España de mutua defensa y ayuda, libertad en la introducción de productos, la libre ciudadanía en todos los países de esta Confederación y la formación de una Comisión de Indemnizaciones. La propuesta fue rápida y rotundamente rechazada por el gobierno de Madrid, como era obvio, y sólo sirvió para demostrar que no todos los hilos de las negociaciones internacionales podían ser controlados por Bolívar. ${ }^{39}$

Santamaría pudo cumplir con éxito su misión, con la firma del Tratado de Amistad, Liga y Confederación entre México y Colombia, firmado el 3 de octubre de $1823 .{ }^{40}$ En el Preámbulo de este Tratado se manifestaba el deseo "de que esta Liga sea general entre todos los Estados de América, (anteriormente españoles) que unidos, fuertes y poderosos puedan sostener en general la causa de su independencia"; ambas naciones se declaraban "unidas, ligadas y confederadas desde ahora para lo sucesivo, en paz y guerra", con el fin de aunar esfuerzos contra España y cualquier otra potencia extranjera, "y asegurar después de su reconocimiento su mutua prosperidad, la mayor armonía y buena inteligencia, tanto entre el pueblo, súbditos y ciudadanos de ambos estados, como con todas las demás potencias con quien deban entrar en relaciones".

Como se ve, las miras iban más allá de la consolidación de la independencia, pues se prometían una unión permanente, y tam-

39 Jos, Emiliano: Una sociedad hispánica de naciones en 1820 según el plan de Francisco Antonio Zea. En Contribuciones para el estudio de la historia de América. Homenaje al Dr. Emilio Ravignani. Buenos Aires, 1941.

40 El texto del Tratado fue impreso en el "Daily National Journal", de Washington, el 18 de mayo de 1825. Algunas de las ediciones modernas son las de Franco, José Luciano (Comp.): Documentos para la Historia de México, La Habana, 1961, págs. 324-327, la del "Boletín de la Academia Nacional de la Historia", tomo XXXV, n. ${ }^{\circ} 139$, Caracas, julioseptiembre de 1952, págs. 302-305, y la de Valle, Rafael Heliodoro: Bolívar en México. 1799 1832, México, 1946, págs. 50-55. 
bién la concertación en cuanto a las relaciones con las naciones extranjeras.

Disponía también el Tratado la formación de una Junta compuesta por dos plenipotenciarios por cada parte, y el compromiso de "interponer sus buenos oficios con los Gobiernos de los demás Estados de América, antes Españoles para entrar.en este pacto de unión, liga y perpetua confederación".

Cuando esto se hubiera obtenido, debía formarse "una asamblea general de los Estados Americanos, compuesta de sus plenipotenciarios, con el encargo de aumentar de la manera más sólida y estable las íntimas relaciones que deben existir entre todos y cada uno de ellos, la cual actuará como un concejo en los mayores conflictos, como punto de contacto en peligros comunes y como un arbitrio y conciliador en sus disputas y diferencias". Por otros artículos se fijaba a Panamá como sede de esa Asamblea, y su eventual traslado a una ciudad mexicana si las circunstancias lo hicieran necesario.

El artículo 17 tocaba uno de los puntos más controvertidos de los esfuerzos integracionistas desarrollados hasta entonces. Establecía que este pacto de unión "no interrumpirá de ningún modo el exercicio de la Soberanía Nacional de cada una de las partes, ya sea con respecto a sus Leyes y el establecimiento y forma de sus respectivos gobiernos o sus relaciones con otros extrangeros".

En este caso ya habían quedado atrás los principios sostenidos por Egaña, de colocar a los intereses generales por encima de los particulares de cada nación. En los años de aquel proyecto del jurista chileno lo inverso hubiera sido más lógico, pues las instituciones que regían a las sociedades políticas estaban aún en ciernes, pero en cambio era prematura la convocatoria al Congreso, pues la suerte de la revolución era incierta y aún no estaba extendida a todos los países hispanoamericanos. Ahora, cuando la guerra tenía amplias perspectivas halagüeñas y la revolución cubría de uno a otro confín, era en este aspecto oportuna la convocatoria, pero en cambio era tardío ya subordinar los principios de las soberanías nacionales a los intereses generales, ni a la soberanía absoluta en cuanto a las relaciones internacionales. 
Por tanto, el bloque que se quería conformar no cubría un aspecto esencial, como era el de reconocer que el peligro de connivencia o complicidad de un gobierno con intereses extraños y lesivos para otro u otros miembros de la Confederación no podía ser objetado por los demás. Durante gran parte del siglo XIX América Latina sería escenario y víctima de agresiones, ingerencias e intervenciones, algunas de ellas con la complicidad de los gobiernos locales, y a esto apuntaban proyectos como el de Egaña.

Las excepciones al ejercicio de la soberanía en relaciones internacionales previstas en este Tratado con México eran la obligación de ambas partes de no acceder al pago de "indemnización, tributos o esacciones... por la pérdida de su antigua supremacía" por parte de España o de cualquier nación, y de no "entrar en ningún Tratado con España o cualquier otra Nación en perjuicio y disminución de nuestra Independencia".

No obstante los términos del Tratado, la actividad de Santamaría en México puso de manifiesto las discordancias políticas entre los dos países. En sus gestiones preliminares había observado que el régimen monárquico impuesto por Iturbide era incompatible con una Liga como la que proponía Colombia, basada en el sistema republicano adoptado por las otras nuevas naciones. Además, la proclividad hacia el absolutismo del Emperador mexicano contradecía también la tendencia general en favor del federalismo y las formas democráticas que prevalecían en las restantes. ${ }^{41}$

Por tal motivo, antes de la firma del Tratado el enviado colombiano había decidido no reconocer oficialmente a Iturbide, y en cambio se asoció a la oposición encabezada por Santana, envolviéndose así en las disputas internas. La lógica respuesta de Iturbide fue desconocer la representación de Santamaría. Poco después el Emperador fue depuesto y entonces las negociaciones se aceleraron y el Tratado fue firmado y complementado por otro de Comercio.

En consecuencia, México envió a Bogotá un encargado de negocios, Anastasio Torréns, iniciándose así las relaciones diplomáti-

41 Núñez Ortega, Ángel: Memorias sobre las relaciones diplomáticas de México con los Estados libres y soberanos de América del Sur, México, Imprenta del Gobierno, 1878. 
cas. El entendimiento prosperó hacia la colaboración de la Gran Colombia en el ataque naval a San Juan de Ulúa, el castillo-fortaleza ubicado frente a Veracruz, que estaba aún en poder de los españoles; cuando la flota colombiana se aprestaba en Cartagena se recibió la noticia de la toma de aquel reducto, haciendo innecesaria su intervención. De todos modos, Torréns no pudo ganarse las simpatías de Bolívar, y terminó siendo despachado por éste.

Por su parte, Mosquera emprendió su camino al sur con iguales instrucciones y esperanzas. No le fue difícil arribar al Tratado de Unión, Liga y Confederación entre Colombia y Perú, firmado en Lima el 6 de julio de $1822 .{ }^{42}$ Su contenido era similar al suscrito con México. Se asumía el compromiso de defensa mutua para asegurar las respectivas independencias, se reconocía la igualdad de derechos de los ciudadanos de una nación en la otra y se fijaba la libre importación y exportación recíprocas. Por un acuerdo adicional, se disponía la formación de una Asamblea integrada por dos plenipotenciarios de cada parte, encargada de velar por el cumplimiento de lo pactado, y el compromiso de invitar a los demás países de la América española a incorporarse a la Liga. Por último, se determinaba la convocatoria a una Asamblea General de Estados Americanos, que debía reunirse en Panamá.

Pocos meses después, el 21 de octubre de 1822, Mosquera lograba su segundo objetivo, al firmar el Tratado de Unión, Liga y Confederación entre Colombia y Chile. ${ }^{43}$ También en este caso se comprometía la unión para defender las independencias, se declaraba la igualdad de los ciudadanos y la libre importación y exportación. Asimismo, disponía formar una Asamblea de plenipotenciarios y se comprometía la invitación a las demás repúblicas; ambas asumían la obligación de no pagar indemnizaciones a España. Como corolario, se resolvía la convocatoria a una Asamblea General de Estados Americanos.

En este caso, la gestión de Mosquera contó con un valioso aliado en Bernardo de O'Higgins, ferviente admirador de Bolívar. El

42 El texto del Tratado en "Boletín de la Academia Nacional de la Historia", tomo XXXV, n." 139, Caracas, julio-septiembre de 1952, págs. 292-296.

43 Ibidem, págs. 297-300. 
chileno escribió al Libertador venezolano adhiriéndose entusiasticamente a la idea del Congreso y reconociendo que sólo él podía tomar tan trascendente iniciativa. ${ }^{44}$

Por su parte, el agente especial de los Estados Unidos en el Perú, Chile y Buenos Aires seguía con atención estos acuerdos y los consideraba altamente beneficiosos para la causa americana, pues los veía como pasos decididos y eficaces para resistir la influencia europea; con excesivo optimismo, entendía que los tratados impedirían asociaciones parciales de estas repúblicas con naciones europeas, y que en este contexto los Estados Unidos serían invitados para presidir el congreso Americano. ${ }^{45}$

El feliz itinerario se frustraría, finalmente, en Buenos Aires. Allí Mosquera tuvo que enfrentarse a la intransigente posición de Rivadavia en contra de todo compromiso con las nuevas Repúblicas; el ministro argentino consideraba conveniente negociar separadamente con España y con cualquier nación europea para el reconocimiento de la independencia. De nada valió que Bolívar anticipara la gestión con una conceptuosa nota al gobierno rioplatense en la que pedía una buena acogida a Mosquera, anunciando su misión"como la salvación del mundo nuevo". ${ }^{46}$ Sólo consiguió un anodino Tratado de Amistad y Alianza, suscrito el 8 de marzo de $1823 .{ }^{47}$

No es posible desvincular la suerte de Mosquera en Buenos Aires con los efectos de la entrevista que Bolívar y San Martín habían sostenido en Guayaquil, sólo unos meses antes. Si bien es pro-

44 De O’Higgins a Bolívar. Valparaíso, 10 de abril de 1823. En Mújica, Relaciones..., pág. 394.

45 De John B. Prevost a John Q. Adams, secretario de Estado de los Estados Unidos, Santiago de Chile, 15 de noviembre de 1822. En Manning, William: Correspondencia diplomática de los Estados Unidos concerniente a la independencia de las naciones latinoamericanas, Buenos Aires, 1930, tomo II, págs. 1.273-1.275.

46 De Bolívar al director supremo de las Provincias Unidas. Cali, 8 de enero de 1822. En Drago, El Congreso de Panamá..., pág. 60.

47 Tratado de Amistad y Alianza entre la República de Colombia y el Estado de Buenos Aires. Buenos Aires, 8 de marzo de 1823. En Registro Oficial de la República Argentina que comprende los documentos expedidos desde 1810 hasta 1873. Buenos Aires, 1880, tomo XX, pág. 38. También en "Revista de Derecho, Historia y Letras", Año XXV, tomo LXXIV, Buenos Aires, 1923, págs. 445-446. En Venezuela fue publicado por el "Boletín de la Academia Nacional de la Historia", tomo XXXV, n." 139, Caracas, julio-septiembre de 1952, pág. 301. 
bable que allí San Martín "aplaudió altamente la Federación de los Estados Americanos como la base esencial de nuestra existencia política" - según el testimonio del secretario de Bolívar- ${ }^{48}$ la entrevista sirvió sin duda más bien para escindir que para unir las dos corrientes libertadoras iniciadas años atrás en Buenos Aires y Caracas. El retiro casi silencioso de San Martín de la escena política y de los campos de batalla y el avance avasallador de Bolívar hacia el sur, daban al gobierno porteño una imagen de empuje y de ocupación de espacios que consideraba propios.

La única voz que se levantó en favor del proyecto de Mosquera fue la de Manuel Moreno, quien, como hemos visto, ya desde 1810 se había iniciado en la idea de una asociación con las otras repúblicas. Ahora Moreno era diputado en la Junta de Representantes y cuando el convenio se discutió en su seno hizo un ardiente alegato en favor de la unión, que provocó una interpelación de la Cámara a Rivadavia; éste se defendió respondiendo con argumentaciones vagas, tales como las inconveniencias de firmar tratados iguales con países diversos y de dejar descubierto así el aumento de fuerzas por grados.

Moreno replicó sosteniendo la comunidad de causas y de objetivos, la semejante posición en el globo, el peligro de enemigos comunes, la identidad en idioma y costumbres. Concluyó que "debía, pues, procurarse en este particular una uniformidad de conducta, y cuando las naciones supiesen que un cañonazo tirado en el cabo de Hornos había de sentirse en Panamá, entonces era que procurarían respetarnos". ${ }^{49}$

Pero su empeño fue inútil. La Junta de Representantes aprobó el proyecto de Rivadavia, que se convirtió en tratado y cuya impresión ocupó menos de media página del Registro Oficial. Sin declarar principio alguno en el Preámbulo, su artículo primero expresaba que ambas partes "ratifican de un modo solemne y á perpetuidad,

48 Del secretario general de Bolívar, José Gabriel Pérez, al intendente del Departamento de Quito. Guayaquil, 29 de julio de 1822. En "Boletín del Archivo Nacional de Quito", año I, n." 1, Quito, enero-junio de 1950, págs. 186-187.

49 Párrafos del texto del discurso en Drago: El Congreso de Panamá... 
por el presente tratado la amistad y buena inteligencia que naturalmente ha existido entre ellos, por la identidad de sus principios y comunidad de sus intereses". Nada se agregaba ni se mejoraba, pues sólo se confirmaba la amistad y entendimiento que se daban por ya existentes, y como éstos habían sido irrelevantes hasta entonces debía suponerse que seguirían siéndolo.

El siguiente fijaba "una reciprocidad perfecta" en cuanto al trato a los ciudadanos de uno y otro Estado; nada se decía respecto a cómo sería ese trato, ni se comprometía preferencia alguna.

El artículo tercero parecía solemnizar un compromiso recíproco, al establecer que ambos "contraen á perpetuidad alianza defensiva en sostén de su independencia"; si el tratado hubiera terminado ahí, habría quedado una puerta abierta a los optimistas. Pero el cuarto anulaba el compromiso, al especificar que "todo caso de alianza será regulado por tratado especial, conforme á las circunstancias y recursos de cada uno de los Estados". Esto es, para que se concretara realmente la alianza prevista en el artículo tercero debía mediar otro tratado, para cuya firma cada uno evaluaría antes su propia situación e interés y obraría en consecuencia. No habría, pues, ningún compromiso asumido. Ambos artículos podrían haber sido omitidos sin que cambiara para nada el contenido del acuerdo. Era un inútil gasto de tinta y papel.

Nada más. Si el texto respondía a formas protocolares que procuraban mantener una amistosa sociabilidad, en rigor debió ser recibido por el gobierno colombiano más bien como una bofetada o como una burla diplomática.

Drago ha sostenido que Mosquera eludió compromisos en cuanto a admitir el principio del uti possidetis de 1810, supuestamente por no convenirle a Colombia en razón de sus diferencias de límites con el Perú. Naturalmente, el interés argentino por asentar ese principio era obtener una sanción condenatoria general a la ocupación brasileña de la Banda Oriental. Lo cierto es que Mosquera no traía instrucciones para aceptarlo; obsérvese que en los tratados con México, Perú y Chile no se mencionó ése ni otro principio respecto a límites. Más bien, se pensaba que debía ser un tema a debatir en el futuro Congreso Americano. 
En tanto, es dudoso que la negativa del colombiano se haya debido a la cuestión limítrofe con Perú, por entonces un problema incipiente. No hay duda que el interés colombiano por la realización del Congreso Americano y de la unión de estos países era entonces una causa muy superior a la de la precisión de los límites de su territorio, de modo que la reducción del Tratado a una porción de palabras inocuas no debe atribuirse a la negativa de Mosquera a esta concesión. Ese rechazo estuvo motivado seguramente por la conveniencia de no hacer aparecer estos acuerdos, que tendían a ser multilaterales, en una oposición abierta contra el Imperio brasileño, ya que el reconocimiento del uti possidetis de 1810 implicaba en esas circunstancias una formal declaración de repulsa a la ocupación de la Banda Oriental por Brasil.

Por el mismo tiempo en que se firmaba este inútil Tratado - o quizá no tan inútil, porque sirvió para avivar el natural recelo de Colombia hacia el gobierno argentino- Buenos Aires suscribía con los comisionados españoles una Convención de Paz, en la que se fijaban indemnizaciones a España. Fue otro motivo de rencor, pues la idea colombiana, plasmada en los otros tratados, era la de concertar solidariamente las negociaciones de arreglo con la antigua metrópoli, y negar en conjunto toda posibilidad de pago de indemnizaciones. El ministro de Relaciones Exteriores colombiano, Pedro Gual, criticó duramente esta Convención, considerándola favorable a la acción de represión española en otras repúblicas, ya que desde entonces deberían suspenderse los auxilios militares de Buenos Aires a Chile y Perú.

La observación de este cuadro negativo haría decir a Bolívar, cuando se preparaba la campaña final contra el ejército español en Perú y que tendría sus momentos decisivos en Junín y Ayacucho, que "de Buenos Aires hay poco que esperar, y así, entre Chile y Colombia debemos hacerlo todo". ${ }^{50}$

No obstante el triunfo de la posición rivadaviana, había en Argentina un sector de opinión favorable a la concertación, el cual era

50 Carta desde Pativilca, del 25 de febrero de 1824. En Bolívar, Simón: Obras Completas, tomo I, págs. 925-926. 
consciente de la necesidad de mancomunar las acciones entre estas Repúblicas, al menos mientras alguna de ellas estuviera en guerra contra España. La prédica de San Martín, de Monteagudo, de Pazos Silva y otros, en favor de un "americanismo" que superara las antinomias locales en beneficio del objetivo común, había dejado su simiente, sumada a la defensa y apología de Bolívar y de sus ideas por Manuel Moreno y el Deán Funes, entre otros. Por eso, no debe extrañar que cuando se tuvo la noticia en Buenos Aires del triunfo final de Ayacucho, los nombres de Bolívar y de Sucre fueran vitoreados en las calles de la ciudad. "Tuve que tirar un decreto para reglamentar el delirio", diría al respecto el gobernador Las Heras, según lo registra Drago.

De todos modos, lo que importaba a los efectos de los acuerdos internacionales era la actitud intransigente del gobierno de Buenos Aires. El resultado de las gestiones de Mosquera provocó cavilaciones en el gobierno colombiano, ya que esto representaba un obstáculo para sus planes de concertación. "Solamente en Buenos Ayres, la política de este gobierno ha encontrado opositores" señalaba el ministro Gual al representante colombiano en Washington, aunque creía que el Tratado "deja el campo abierto á una nueva negociación". ${ }^{51}$ Con esa esperanza, instruyó al diplomático para que interesara al gobierno de los Estados Unidos a que interviniera activamente en la convocatoria, y que utilizara su influjo para ablandar actitudes como la del gobierno de Buenos Aires, pensando probablemente que bajo esa sugestión se lograría firmar un nuevo tratado conforme a las previsiones del artículo cuarto.

\section{Los prolegómenos del Congreso de Panamá}

Por los mismos años en que se desarrollaban las largas tratativas de Santa María y Mosquera, otras gestiones eran llevadas a

51 AHNC, República, Miscelánea, tomo 24, fols. 181 a 183. De Pedro Gual, ministro de Relaciones Exteriores de la Gran Colombia, a José María Salazar, ministro plenipotenciario en los Estados Unidos, Bogotá, 7 de octubre de 1824. 
cabo por distintos gobiernos para ganar voluntades en favor de la realización del Congreso.

Un acontecimiento europeo motivó la activación de estos empeños, y provocó la necesidad de urgir la convocatoria. En efecto, al restablecerse el absolutismo en España a fines de 1823, fueron retiradas y anuladas las comisiones pacificadoras enviadas por el anterior gobierno liberal con ánimo conciliatorio, y como consecuencia se reactivaron los rumores de amenaza de una intervención armada de los países de la Santa Alianza para reintegrar las colonias americanas a España.

El peligro potencial tuvo también el efecto de acentuar la atención en el posible apoyo de los Estados Unidos, y en requerir su intervención activa en el Congreso de Panamá. Fue ésta la primera vez, según parece, que un gobierno de las nuevas repúblicas intentó apelar a la flamante Declaración de Monroe sobre la separación del mundo americano del europeo y la oposición de los Estados Unidos a toda forma de restauración del colonialismo europeo en América. Las instrucciones que el enviado colombiano en los Estados Unidos recibió de su gobierno fueron explícitas en ese sentido, y demostrativas de que el peligro de la Santa Alianza obligaba a reformular los planes relacionados con la convocatoria al Congreso. ${ }^{52}$

La inquietante novedad llevó incluso al gobierno anfitrión a reconocer el posible liderazgo de los Estados Unidos en la Asamblea, resignando así una jefatura que hasta entonces parecía incuestionable en favor de Bolívar y del gobierno grancolombiano. Así puede inferirse de las instrucciones citadas, en las que la vigencia de la Doctrina de Monroe aparece como el recurso salvador ante la amenaza europea.

Como el gobierno de los Estados Unidos había declarado su neutralidad en la guerra de independencia hispanoamericana, era necesario replantear los temas del Congreso para asegurar su participación. Así el gobierno colombiano pensó que para estimular la presencia estadounidense, esos temas debían reducirse al compromiso de exigir que se pusiera término a toda especie de colonización

52 Ibídem. 
europea en América, a "denunciar la aplicación de los principios constitutivos de la Santa Alianza, como perjudiciales a la paz y seguridad de dichos Estados Unidos" (lo cual debería ser tratado en forma reservada), y "á convenir sobre todos y cada uno de los puntos controvertibles de derecho marítimo en tiempos de guerra, a fin de hacer más duraderas y estables las relaciones de paz, amistad, comercio y navegación, que se están estableciendo entre todas".

A todo esto habría que añadir aún el problema de la dilatación de la campaña militar en el Perú, lo que originaba los primeros síntomas de malestar por la presencia gravosa de fuertes contingentes extraños en su territorio (el ejército estaba formado por chilenos, argentinos, ecuatorianos, colombianos...), y a que en México Iturbide no cejaba en sus empeños de restablecer una autoridad absoluta.

En tanto, otra misión emprendía un largo camino en busca de la concertación y la solidaridad. El gobierno de Guatemala envió un comisionado que debía llegar hasta Buenos Aires, pero haciendo una estancia en territorio grancolombiano para buscar allí un apoyo a sus gestiones. En efecto, el plenipotenciario Pedro Molina obtuvo el beneplácito de Bolívar, que vio en la misión un elemento favorable a sus planes. Ya Bolívar había recibido de Monteagudo una recomendación en favor de Molina, en la que le comunicaba que el propósito de su viaje era "llevar a efecto la deseada Federación Americana", de modo que por su parte aconsejó a Santander que apoyara la gestión de Molina. ${ }^{53}$ Así, el guatemalteco pudo firmar en Bogotá un Tratado de Liga y Unión.

Ya en Guayaquil, Molina envió una nota al gobierno de Buenos Aires anunciando sus propósitos, que consistían en acordar "el reconocimiento recíproco de nuestra independencia, tratados de alianza y auxilios mutuos y de comercio". El ministro argentino García, por lo que se conoce, se limitó a una respuesta protocolar, asegurándole que a su arribo se le daría "la consideración que le merece su persona, como igualmente el Gobierno que lo envía". Transcurrió más de un año hasta que se produjera esta respuesta: ignora-

53 De Bolívar a Pedro Molina. Huariaca, 17 de julio de 1824. En Bolívar: Obras Completas, tomo II, págs. 21-22. 
mos dónde estaría por entonces Molina, pero es improbable que esperara tanto tiempo. ${ }^{54}$ De todos modos, por lo que se sabe, la gestión no fue más allá de este cambio de notas.

En verdad, debía suponerse que el envío de un comisionado del gobierno de Guatemala para establecer alianzas con las repúblicas sudamericanas estaba ligado a la necesidad de afirmar su propia nacionalidad ante las ya conocidas y ejercitadas pretensiones de México por absorber este país, y al interés del gobierno de Guatemala de afianzar la federación centroamericana con una posición predominante frente a las otras repúblicas del sector.

Era inevitable que misiones como las de Molina incluyeran el doble propósito de la concertación para precaverse de enemigos externos y el de afianzar su propia nacionalidad frente a los vecinos. A la hora de tratar acuerdos con las demás repúblicas o de reunirse en un congreso general, resultaba difícil deslindar o desvincular ambos objetivos, con lo que los esfuerzos de concertación general aparecían desvirtuados.

A estas actividades diplomáticas y políticas se sumaban por entonces las reflexiones de pensadores que sostenían principios integracionistas y proponían fórmulas y modos de llevarlos a la práctica. Uno de ellos fue el hondureño José Cecilio del Valle, quien en 1822 publicó su proyecto de Federación Americana y de realización en Costa Rica de un Congreso General para acordar sus bases.

También el argentino Bernardo de Monteagudo elaboró en 1824 un Ensayo sobre la necesidad de una federación general entre los Estados Hispanoamericanos y plan de su organización; Monteagudo entendía que desde 1821 se había abierto el camino, al quedar unidos el norte y el sur con la incorporación del Perú a la revolución. Aunque creía que el método era el de reconocer el impulso "de una sola mano" - obviamente la de Bolívar-, sostenía el democrático principio de que la federación debía ser en beneficio de los pueblos en su totalidad "y no los de algunas familias".

54 AGNA, X-1-10-3. Pedro Molina al ministro de Relaciones Exteriores del Gobierno de Buenos Aires. Guayaquil, 2 de julio de 1824. Sólo nos ha sido posible inferir la respuesta del ministro García por la minuta firmada y escrita al margen de esta nota con fecha 24 de agosto de 1825. 
La de Monteagudo fue una voz peculiar en el conjunto de partidarios de la integración y del encuentro en un Congreso Americano; levantó el ideal de la "soberanía de los pueblos", con lo que quitaba al concepto de soberanía el sentido localista con que se aludía a él en aras de un afianzamiento de las nacionalidades, y opuso ese concepto contra las ambiciones de la Santa Alianza, que levantaba en cambio el principio de legitimidad, utilizado como "divisa para condenar la soberanía de los pueblos". En cuanto al funcionamiento de la Asamblea, postulaba que ésta debía dirigir la política interior y exterior de estos países durante los diez años siguientes al reconocimiento de la independencia, con lo que se obtendría la más eficaz garantía de respeto a esa independencia. ${ }^{55}$

En los años anteriores al Congreso Americano, como se ve, habíanse gestado proyectos, iniciado tratativas y realizado acciones concretas que fueron preparando el camino que conducía a Panamá. Pero era un camino sinuoso, cubierto de espinas y que no pudo ser desbravado a lo largo de todas estas gestiones.

Dos grupos de problemas debieron enfrentarse, y ninguno pudo ser superado. Uno era el de los términos de la concertación misma entre las nuevas naciones. El otro, el de la comprensión y el apoyo de las potencias para que el Congreso fuera respetado y reconocido como una expresión legítima en el orden internacional. Lo segundo dependía de lo primero, pues era obvio que el respeto se conseguiría a partir de la solidez con que estos países establecieran sus vínculos y estrecharan sus filas.

Otra de las cuestiones que estaban en la base de la convocatoria y que suscitaba hondas controversias era cuáles serían los Estados convocados, para lo que era previo determinar cuáles serían los criterios que determinarían quiénes debían conformar la futura

55 Las primeras ediciones del Ensayo aparecieron en Lima y Santiago de Chile, en 1825. Impresiones modernas en Escritos. Buenos Aires, 1989, y en Escritos Políticos. Buenos Aires, s/f. Variados juicios mereció el opúsculo, desde los que lo consideran un impulsor decisivo para la realización del Congreso de Panamá, hasta los que entienden que sólo tuvo la intención de halagar a Bolívar (como lo sostiene Drago), y los que creen que no influyó de ninguna manera en el pensamiento de éste (como lo afirma Paz Soldán). 
Confederación Americana. Cuestiones políticas, culturales y étnicas gravitaron en las especulaciones, tanto para las invitaciones como para su aceptación. Así, Paraguay no fue tenido en cuenta en ningún momento como probable invitado; Haití fue también dejado de lado por decisión de Santander, por ser su población de origen africano, y para evitar el desagrado de Francia. ${ }^{56}$

El caso de Brasil fue el más delicado y complejo. Un país de enorme superficie, con extensas fronteras, todas ellas conflictivas, que lo separaban de la totalidad de las repúblicas sudamericanas con excepción de Chile -Ecuador aún se consideraba limítrofe del Imperio- y de tres dominios europeos; poseedor, además, de la mayor parte de la cuenca del Amazonas y dueño de la desembocadura de ese río, cuyos afluentes bañan varias repúblicas andinas. Desde esta perspectiva, era de fundamental interés común su ingreso a esta proyectada comunidad.

Pero por otra parte, había allí una monarquía personificada en un miembro de una dinastía legítima europea, con lazos de parentesco con otras familias reales igualmente legítimas. Como era natural, la idea legitimista europea condenaba toda revolución, por lejana que fuese. Desde esta perspectiva, la aparición de Brasil como estado en América podía ser vista como la prolongación de un reino europeo. Por añadidura, Brasil había adoptado la forma Imperial, con un ambicioso programa para justificar su dominación. Y allí se mantenía el régimen de la esclavitud, como una de las bases de la producción y como aspecto decisivo de la estructura social. Como si esto fuera poco, había renovado el varias veces secular problema de la Banda Oriental que había enfrentado en la época colonial a España y Portugal, y ahora la cuestión alcanzaba la mayor gravedad al desatarse, en 1825, la guerra con Argentina para dirimir finalmente el destino de ese país.

Si bien no cabían dudas de que el Brasil debía formar parte del magno Congreso, todos sabían que era un socio conflictivo, que traería a la mesa de negociaciones más problemas que soluciones.

56 Castillero R., Ernesto J.: Intimidades del Congreso de Panamá de 1826. Panamá, 1961 
En efecto, el Imperio aceptó la invitación pero manteniendo la pretensión de que no se tratara sobre la forma de gobierno - la suya, por supuesto, era denostada por el resto de los convocados-, ni la cuestión de la Banda Oriental - que era considerada mayoritariamente como una usurpación brasileña-; también sostuvo que no debían adoptarse medidas de hostilidad común contra España -que no era su enemiga, puesto que ya ni Portugal era considerado como un peligro para el Imperio- y que Gran Bretaña no fuera invitada. No abandonaba, por otra parte, su pretensión de ser considerado como el miembro mayor de la Asamblea.

Con todos estos antecedentes, el Brasil aparecía como un convidado molesto, pero inevitable. El retorno de su representante, cuando había hecho medio camino hacia Panamá, no representó una solución. La disyuntiva era crucial, pues tanto su participación como su ausencia incidían de manera negativa. Su presencia, porque ella obligaba a enfrentar cuestiones prácticamente insolubles o a soslayar problemas fundamentales; su ausencia, por la omisión de un actor decisivo de la América emancipada.

Una cuestión más era necesario aún discutir y consensuar; la participación de naciones que estaban fuera del ámbito de los países emancipados, pero que tenían en él directos e importantes intereses económicos y políticos. Se trataba también de una situación compleja, que se esquematizaba en tres posibles alternativas; una de ellas era su exclusión, con el criterio de que la Asamblea debía estar reservada exclusivamente a los involucrados en el proceso de emancipación; otra era la invitación a una o a varias naciones, en una selección que atendiera a futuras relaciones deseables. $Y$ finalmente, hacer una participación indiscriminada, dejando así a las naciones la decisión de concurrir o no.

También debió decidirse si esta o estas naciones podrían participar con sus opiniones o si sólo podrían enviar observadores; en este punto las posiciones mayoritarias fueron de admitirlas sólo como observadoras. De todos modos, la sola presencia de estos delegados, y por tanto la oportunidad de hacer oír su voz ante los diputados dentro del recinto o en las antecámaras, debía tener un peso considerable en las posibles decisiones. 
Los intercambios de notas entre los gobiernos, las especulaciones que en cada país se hicieron al respecto, los informes de diplomáticos de uno a otro lado del océano, muestran que este asunto era considerado como de máxima importancia. Finalmente, el problema quedó esquematizado en la disyuntiva de optar por la presencia de una potencia europea -obviamente Inglaterra-, o su exclusión y la ocupación de ese lugar por los Estados Unidos, que ya se habían manifestado por el principio de la separación de Europa y América, sentando la teoría del aislacionismo en sus relaciones exteriores.

Quienes se inclinaban por Inglaterra, lo hacían primordialmente por la coyuntura especial de entonces, ocasionada por la amenaza de los países agrupados en la Santa Alianza, constituida con el ánimo de restablecer las instituciones tradicionales y exigir el acatamiento a las dinastías legítimas; creían que la protección de la potencia insular europea representaría una garantía para neutralizar aquellos intentos en América. El gobierno peruano, que se convirtió en el co-anfitrión de la Asamblea y asumió la tarea de comprometer a los países centroamericanos, a Chile y Argentina en la asistencia a Panamá, adoptó esa posición. Así lo expuso el Ministro de Relaciones Exteriores peruano, al sostener que "el proyecto de que la Gran Bretaña se haga aliada de la Confederación es tan ventajoso que realizado, parece, que la Confederación tomaría el último grado de firmeza, y que su éxito sería tan feliz como es de esperar". ${ }^{57}$

Pero el mismo temor a la Santa Alianza movía a los partidarios de inclinarse hacia los Estados Unidos, en este caso por creer que Inglaterra sería finalmente un aliado de los intereses europeos en las disputas con América, o en todo caso porque los Estados Unidos serían más firmes opositores de aquellos propósitos de restauración.

La posición de Bolívar fue ecléctica, y varió con el tiempo, conforme a las circunstancias que observaba. En la Carta de Jamai-

57 Hipólito Unanue a Cristóbal Armero, agente de Negocios de Colombia. [Lima], 14 de enero de 1826. En Porras Barrenechea, Raúl: El Congreso de Panamá (1826), Lima, 1930, págs. 50-51. 
ca se había pronunciado por excluir a los Estados Unidos, por razones de religión, idioma y costumbres, pero luego admitió la conveniencia de aceptar algunas de sus sugestiones y de admitir su presencia en Panamá. En vísperas del Congreso y cuando ponía su atención en la unión formada por Bolivia, Perú y Colombia, pensó en la conveniencia de una Confederación "más estrecha que la de los Estados Unidos", lo que apareció como una incongruencia con respecto al pensamiento expresado en la Carta de Jamaica. ${ }^{58}$ No obstante, es preciso tener en cuenta que las cosas habían cambiado desde entonces, y que ahora se trataba de un sistema político a implantar y no la incorporación de los Estados Unidos a una Confederación Americana.

El gobierno de Buenos Aires prefirió la presencia de los Estados Unidos, motivado fundamentalmente por la conveniencia de poner un contrapeso a la autoridad de Bolívar.

Es claro que todas estas eran especulaciones basadas en suposiciones, pues por su lado las potencias no elaboraban sus políticas en función de los tanteos diplomáticos de los gobiernos hispanoamericanos, sino de principios estructurados en una política exterior que respondía a sus intereses propios; las instrucciones que el delegado norteamericano recibió de su gobierno para su actuación en Panamá, dan un claro indicio de que consideraba casi intrascendente al Congreso, que no le atribuía capacidad legislativa, y que estaba resuelto a no adquirir compromisos. ${ }^{59}$

58 Bolívar a Antonio Gutiérrez de la Fuente. Magdalena, 12 de mayo de 1826. En Bolívar: Escritos Políticos, págs. 153-156. Y en Ortiz de Zevallos-Paz-Soldán: La misión Ortiz de Zevallos en Bolivia (1826-1827), Lima, 1956, págs. LVIII-LIX.

59 Instrucciones a los representantes de Estados Unidos en el Congreso de Panamá. Washington, 8 de mayo de 1826. En Aranda, Ricardo: Congresos y Conferencias en que ha tomado parte el Perú. Lima, Imp. de la Revista, 1909, tomo I, págs. 24-36. Se les decía: "El Presidente está persuadido que dicho Congreso es puramente diplomático, sin que pueda revestirse del carácter legislativo; es decir, que ninguno de los Estados representados en él debe quedar sujeto a un tratado, convención, pacto o acto, al que no haya consentido su Representante, y que además para su validez, es indispensable la ratificación de los Estados interesados con arreglo a su Constitución... Se rechaza, por tanto, toda pretensión de establecer un Consejo Anphictionico, que tratase de abrogarse facultades para decidir controversias entre los diversos Estados americanos o arreglar su conducta... Los congresos, que últimamente han sido tan comunes en Europa, han sido puramente diplomáticos...". 
Finalmente serían invitados como observadores tanto los Estados Unidos como Inglaterra, además de Francia y los Países Bajos.

Desde esta perspectiva, el Congreso de Panamá suponía un gran desafío; era necesario demostrar la capacidad de lograr la unión y de exhibir una fuerza suficiente para defender en forma mancomunada las independencias y las libertades ganadas en la revolución. Lo contrario, esto es el fracaso del Congreso, demostraría a las potencias la esterilidad de los empeños solidarios y la consiguiente debilidad de las nuevas naciones, tomadas una a una, y por tanto la facilidad con que podrían ser impuestas condiciones que afectarían el reconocimiento pleno de las independencias.

La superación del primer problema exigía renunciamientos a la soberbia que se ocultaba bajo el velo de las pretendidas soberanías nacionales. Las ambiciones personales y las pretensiones de supremacía de unas naciones sobre otras engendrarían las lógicas prevenciones y suspicacias.

En su afán imitativo, no se reparó en que las soberanías locales se explicaban y justificaban en el marco de una lucha por afirmar la propia identidad de naciones entre sí mismas, como era el caso de las europeas, y no de un mundo colonial frente a un mundo imperial, como era el caso de las nuevas naciones en la futura América Latina.

La fragmentación del espacio colonial era todo lo que convenía a antiguos y modernos imperios, para conservar y confirmar viejas hegemonías o imponer las nuevas. Por lo contrario, la acción compacta del mundo colonial por afirmar las independencias y apuntalar recíprocamente el feliz nacimiento de las nuevas nacionalidades debía constituir un formidable escollo a las ambiciones de los imperios. La afirmación es obvia, pero parece necesaria a la luz no sólo de las mentalidades de aquella época sino también de algunos enfoques historiográficos del presente.

Los dos polos de este ambiente enrarecido por los recelos se focalizaron, por una parte, en la figura de Bolívar, en quien sus rivales veían el peligro de la autocracia; y por la otra, al gobierno de las Provincias Unidas del Río de la Plata, conducido por el prime- 
ro ministro y luego presidente Rivadavia. El uno apareció para algunos como la amenaza de asumir por sí la autoridad suprema y dictatorial, ahogando los federalismos y las autonomías nacionales; el otro, como el soberbio que se consideraba dueño de disponer por sí, sin ayuda de vecinos, la afirmación de su nacionalidad con el beneplácito y el apoyo de las naciones más poderosas.

Una señal del pensamiento rivadaviano al respecto, entre prescindente y soberbio, la dio su manifestación al representante norteamericano, a quien afirmó que su gobierno seguiría la misma conducta que los Estados Unidos en cuanto a su intervención en el Congreso de Panamá. ${ }^{60}$ La expresión es significativa pues, por una parte, estaba mostrando que Argentina no temía la agresión europea, como no la podían temer ya los Estados Unidos, y que, en todo caso, su participación en el Congreso sería como la de los Estados Unidos, esto es sin comprometerse a asumir causas que no fueran las de un estricto interés propio. La soberbia, la autosuficiencia, la indiferencia y el sentido de superioridad se combinan en la escueta declaración del presidente argentino.

Uno y otro - Bolívar y el gobierno argentino-, hicieron lo suyo para dar pie a las sospechas, para fundamentar los recelos y desconfianzas. Debe decirse, sin embargo, que la actitud del primero era la opción natural de los tiempos y, visto en perspectiva, una condición necesaria para lograr la unión y la solidaridad en un ámbito enrarecido y convulsionado por los rigores de las contiendas contra la metrópoli y aún por las disputas entre las facciones locales, regionales y provinciales. El reconocimiento a una autoridad superior, adquirida por el prestigio político y por la victoria en los campos de batalla, era el respaldo necesario para lograr la unión deseada, dadas las circunstancias de entonces. Y esas eran las condiciones que reunía un solo hombre, como Monteagudo lo había proclamado: Bolívar.

60 John M. Forbes a Henry Clay, Buenos Aires, 20 de marzo de 1826. En Quesada Zapiola, Carlos A.: Catálogo de la documentación referente a las relaciones diplomáticas entre los Estados Unidos de América y la República Argentina. 1810-1830. Existente en el Archivo Nacional de los Estados Unidos de América (Sección Departamento de Estado). Buenos Aires, 1948, pág. 17. 
El segundo, en cambio, representaba la antítesis de la posición bolivariana. La soberbia de considerarse autosuficiente encerraba también la convicción de superioridad frente a sus vecinos.

De nada valió que en Buenos Aires se levantaran voces discordantes, aún dentro del propio gobierno. El mismo gobernador Las Heras se hizo eco de la demanda, y llegó a comprometerse ante el gobierno del Perú a enviar diputados a Panamá. ${ }^{61}$ La presión ejercida llevó así a una aceptación preliminar y corrió el rumor, tomado por Domingo Funes como cierto, que había sido designado Manuel Moreno. Un decreto nombró luego a Manuel José García, pero éste no aceptó y más tarde la nominación recayó en José Miguel Díaz Vélez, quien aún no había regresado de Chuquisaca cuando el Congreso ya era inaugurado; por lo demás, habiendo aceptado concurrir a Panamá, se demoró en Bolivia para resolver conflictos políticos en ese país. Estas idas y venidas en la designación de diputados parecen indicar que se trataba sólo de fuegos de artificio.

De todos modos, la autorización que el Congreso había dado al Ejecutivo para que enviara representantes tenía idéntica limitación que el Tratado firmado con la Gran Colombia unos años atrás, pues su artículo quinto determinaba que toda alianza sería acordada por "tratado especial, conforme a las circunstancias y recursos de cada uno de los estados contratantes". ${ }^{62}$ Ya se ha visto que aquel Tratado era inútil, e igualmente lo sería la ley de autorización al Ejecutivo, puesto que sólo lo facultaba a enviar delegados, sin plenipotencia alguna.

También debió incidir en la confusa situación creada en Buenos Aires el hecho de que los Estados Unidos e Inglaterra hubieran decidido estar presentes en Panamá. Esta noticia debió inclinar momentáneamente los ánimos en favor de la asistencia; en ese sentido, el ministro de Relaciones Exteriores fue explícito al informar a Ignacio Álvarez Thomas, que cumplía una misión en Chile, que la concurrencia de delegados de aquellos países había apurado una de-

61 Juan Gregorio de Las Heras y Manuel J. García al Gobierno del Penú. Buenos Aires, 9 de septiembre de 1825. En Porras Barrenechea, El Congreso de Panamá..., pág. 135.

62 Lascano, Víctor: América y la política argentina. Antecedentes diplomáticos e históricos. Buenos Aires, 1938. Segunda Parte, págs. 5-7. 
cisión favorable por parte del gobierno argentino. ${ }^{63}$ Esto podría resolver, entre otras cosas, que se desbaratase en el Congreso el concierto entre México y Colombia para obrar conjuntamente por la fuerza en favor de la independencia de Cuba y Puerto Rico, proyecto en el cual el gobierno argentino no quería verse involucrado de manera alguna y que ya había recibido el rechazo de los Estados Unidos y de Inglaterra. Así lo manifestó el ya presidente Rivadavia al representante norteamericano en Buenos Aires. ${ }^{64}$

Pero el Congreso se inauguró y se clausuró sin la presencia de ningún delegado rioplatense. De esa manera, Argentina inició su camino hacia la afirmación de sus instituciones políticas en el aislamiento y separación del contexto latinoamericano, desentendiéndose ostensiblemente de la problemática general del sub-continente. El objetivo de sus dirigentes de entonces, que sentaron escuela y formaron discípulos perfeccionadores del sistema, fue obtener el respeto de las naciones europeas precisamente a partir de la pretendida demostración de que no formaban parte de aquellos pueblos, a los que veía inmersos en un estado de caos y de convulsiones políticas y sociales de las que creía no participar.

La observación del cuadro general ofrecía aspectos diversos, complejos y contradictorios. Se mezclaban los intereses de hombres, pueblos, regiones, pero no aún naciones en el sentido actual del término. En el mejor de los casos, la "nación" era una idea en la mente de los más esclarecidos. En la generalidad de los dirigentes, unos veían a los jefes de la revolución como providenciales, aureolados por el esplendor de la victoria; otros, en cambio, los veían teñidos con las pasiones del poder y de las ambiciones desmedidas.

Para unos aparecían las regiones o los países como los ámbitos que debían llenarse de un contenido sustancial como fundamento de la nacionalidad, para lo cual creían necesario distinguir esos espacios diferenciándolos y acotándolos con respecto a los otros, ya sea ensanchando sus límites lo más ampliamente posible, ya armán-

63 Del ministro de Relaciones Exteriores, Francisco de la Cruz, a Ignacio Álvarez. Thomas. Buenos Aires, 24 de abril de 1826. En Drago, El Congreso de Panamá..., pág. 180.

64 Forbes a Henry Clay. Buenos Aires, 17 de junio de 1826. En Forbes, John Murray: Ance años en Buenos Aires. 1820-1831. Buenos Aires, 1956, págs. 425-428. 
dose y precaviéndose ante la posibilidad de ser disputados sus territorios por los vecinos. Crearon así un sentido de la soberanía referido a las inmediaciones, al peligro de asalto vecinal, pero vulnerable en cambio a las apetencias que vinieran del otro lado del océano o del norte del continente, facilitadas precisamente por la falta de solidaridad entre los pasibles de semejantes agresiones.

Distintas concepciones con respecto al ejercicio de la autoridad y a la afirmación de las soberanías marcaron esta etapa definitiva, en que los pueblos latinoamericanos debían decidir las formas de su inscripción en el mundo como naciones de hecho y de derecho.

Al prevalecer las posiciones aislacionistas y postergar a las congregacionistas, las incipientes naciones celebraron como máxima conquista la independencia política propia, de diversa manera menguadas todas ellas. Debieron ocultar, disimular y explicar con ánimo justificatorio el fracaso de la reunión y de la mancomunidad, como si aquellos intentos hubieran sido, en su hora, la negación de las soberanías, cuando en rigor eran la forma más apropiada a las circunstancias para confirmarlas.

Muchas de estas consideraciones y quizá algunas otras que se nos escapan debieron ocupar la mente de los diputados que iban llegando a la sede del Congreso, en espera de la solemne inauguración, mientras observaban el romper de las olas frente al istmo con que la naturaleza hizo una a América Latina. No podemos saber cuáles fueron sus semblantes y si ellos revelaban optimismo o escepticismo, si prevalecía la ilusión por la deseada integración, o si en cambio eran conscientes de la realidad que vivían y que debían representar. Pero es seguro que si prevalecía lo segundo, sus rostros no habrían podido evitar un rictus de tristeza y desconsuelo.

Sin embargo, el más sensato habrá pensado - es bueno imaginarlo así- que alguna vez llegaría la hora en que a la mesa de deliberaciones se sentarían los legítimos representantes de todos los pueblos latinoamericanos, imbuidos de una auténtica vocación de solidaridad, y que sólo entonces la América Latina estaría transitando el verdadero camino de la libertad y de la independencia. 